\title{
The contribution of oceanic halocarbons to marine and free tropospheric air over the tropical West Pacific
}

\author{
Steffen Fuhlbrügge ${ }^{1}$, Birgit Quack ${ }^{1}$, Susann Tegtmeier ${ }^{1}$, Elliot Atlas ${ }^{2}$, Helmke Hepach ${ }^{1}$, Qiang Shi ${ }^{3}$, \\ Stefan Raimund ${ }^{4}$, and Kirstin Krüger ${ }^{5}$ \\ ${ }^{1}$ GEOMAR Helmholtz Centre for Ocean Research Kiel, Kiel, Germany \\ ${ }^{2}$ Rosenstiel School for Marine and Atmospheric Sciences, Miami, Florida, USA \\ ${ }^{3}$ Department of Oceanography, Dalhousie University, Halifax, Canada \\ ${ }^{4}$ SubCtech GmbH, Roscoff, France \\ ${ }^{5}$ Department of Geosciences, University of Oslo, Oslo, Norway \\ Correspondence to: Kirstin Krüger (kirstin.krueger@geo.uio.no)
}

Received: 26 March 2015 - Published in Atmos. Chem. Phys. Discuss.: 2 July 2015

Revised: 30 April 2016 - Accepted: 12 May 2016 - Published: 21 June 2016

\begin{abstract}
Emissions of halogenated very-short-lived substances (VSLSs) from the oceans contribute to the atmospheric halogen budget and affect tropospheric and stratospheric ozone. Here, we investigate the contribution of natural oceanic VSLS emissions to the marine atmospheric boundary layer (MABL) and their transport into the free troposphere (FT) over the tropical West Pacific. The study concentrates on bromoform, dibromomethane and methyl iodide measured on ship and aircraft during the SHIVA (Stratospheric Ozone: Halogen Impacts in a Varying Atmosphere) campaign in the South China and Sulu seas in November 2011. Elevated oceanic concentrations for bromoform, dibromomethane and methyl iodide of on average 19.9, 5.0 and $3.8 \mathrm{pmol} \mathrm{L}^{-1}$, in particular close to Singapore and to the coast of Borneo, with high corresponding oceanic emissions of 1486,405 and $433 \mathrm{pmol} \mathrm{m}^{-2} \mathrm{~h}^{-1}$ respectively, characterise this tropical region as a strong source of these compounds. Atmospheric mixing ratios in the MABL were unexpectedly relatively low with $2.08,1.17$ and $0.39 \mathrm{ppt}$ for bromoform, dibromomethane and methyl iodide. We use meteorological and chemical ship and aircraft observations, FLEXPART trajectory calculations and source-loss estimates to identify the oceanic VSLS contribution to the MABL and to the FT. Our results show that the well-ventilated MABL and intense convection led to the low atmospheric mixing ratios in the MABL despite the high oceanic emissions. Up to $45 \%$ of the accumulated bromoform in the FT above the region originates from the local South China Sea area, while dibro-
\end{abstract}

momethane is largely advected from distant source regions and the local ocean only contributes $20 \%$. The accumulated methyl iodide in the FT is higher than can be explained with local contributions. Possible reasons, uncertainties and consequences of our observations and model estimates are discussed.

\section{Introduction}

Halogens play an important role for atmospheric chemical processes. Chlorine, bromine and iodine radicals destroy ozone in the stratosphere (e.g. Solomon, 1999) and also affect tropospheric chemistry (e.g. Saiz-Lopez and von Glasow, 2012). Halogens are released following the photochemical breakdown of organic anthropogenic and natural trace gases. A large number of very-short-lived brominated and iodinated organic substances, originating from macroalgae, phytoplankton and other marine biota, are emitted from tropical oceans and coastal regions to the atmosphere (Gschwend et al., 1985; Carpenter and Liss, 2000; Quack and Wallace, 2003; Quack et al., 2007; Liu et al., 2013). In particular, marine emissions of bromoform $\left(\mathrm{CHBr}_{3}\right)$, dibromomethane $\left(\mathrm{CH}_{2} \mathrm{Br}_{2}\right)$ and methyl iodide $\left(\mathrm{CH}_{3} \mathrm{I}\right)$ are major contributors of bromine and iodine to the atmosphere (Montzka and Reimann, 2011). Annually averaged mean tropical lifetimes of these halogenated very-short-lived substances (VSLSs) in the boundary layer are 15 (range: 13- 
17) days for $\mathrm{CHBr}_{3}, 94$ (84-114) days for $\mathrm{CH}_{2} \mathrm{Br}_{2}$ and 4 (3.8-4.3) days for $\mathrm{CH}_{3} \mathrm{I}$. The mean tropospheric lifetimes of these compounds at $10 \mathrm{~km}$ height are $17(16-18)$ days, 150 (144-155) days and 3.5 (3.4-3.6) days respectively (Carpenter et al., 2014). Climate change could strongly affect marine biota and thereby halogen sources and the oceanic emission strength (Hughes et al., 2012; Leedham et al., 2013; Hepach et al., 2014).

Aircraft measurements from Dix et al. (2013) suggest that the halogen-driven ozone loss in the free troposphere (FT) is currently underestimated. In particular, elevated amounts of the iodine oxide free radical in the FT over the Central Pacific indicate that iodine may have a larger effect on the FT ozone budget than currently estimated by chemical models. Coinciding with this study, Tegtmeier et al. (2013) projected a higher $\mathrm{CH}_{3} \mathrm{I}$ delivery to the upper troposphere/lower stratosphere over the tropical West Pacific than previously reported, using an observation-based emission climatology by Ziska et al. (2013). Recent studies reported significant contributions of bromine and iodine to the total rate of tropospheric and stratospheric ozone loss (e.g. von Glasow et al., 2004; Yang et al., 2005, 2014; Saiz-Lopez et al., 2014; Hossaini et al., 2015). Deep tropical convective events (Aschmann et al., 2011; Tegtmeier et al., 2013; Carpenter et al., 2014) as well as tropical cyclones, i.e. typhoons (Tegtmeier et al., 2012), are projected to transport VSLSs rapidly from the ocean surface to the upper tropical tropopause layer. Despite the importance of halogens on tropospheric and stratospheric ozone chemistry, halogen sources and transport ways are still not fully understood. While the tropical West Pacific comprises strong VSLS source regions (Krüger and Quack, 2013), only low mean atmospheric mixing ratios were observed during ship campaigns in 1994 and 2009 (Yokouchi et al., 1997; Quack and Suess, 1999) and in 2010 (Quack et al., 2011; Brinckmann et al., 2012). None of these previous studies investigated the contribution of oceanic VSLS emissions to the marine atmospheric boundary layer (MABL) and to the FT in this hotspot region with large oceanic sources and strong convective activity.

The SHIVA (Stratospheric Ozone: Halogen Impacts in a Varying Atmosphere) ship, aircraft and ground-based campaign during November and December 2011 in the Southern South China and Sulu seas investigated oceanic emission strengths of marine VSLSs, as well as their atmospheric transport and chemical transformation from the ocean surface to the upper troposphere. For more details about the SHIVA campaign see the ACP special issue (Sturges et al., 2012).

In this study, we present campaign data from the research vessel (R/V) Sonne and the research aircraft (R/A) Falcon. We identify the contribution of oceanic emissions to the MABL and their exchange into the FT applying in situ observations, trajectory calculations and source-loss estimates. The results are crucial for a better process understanding and for chemical transport model validation (Hossaini et al.,

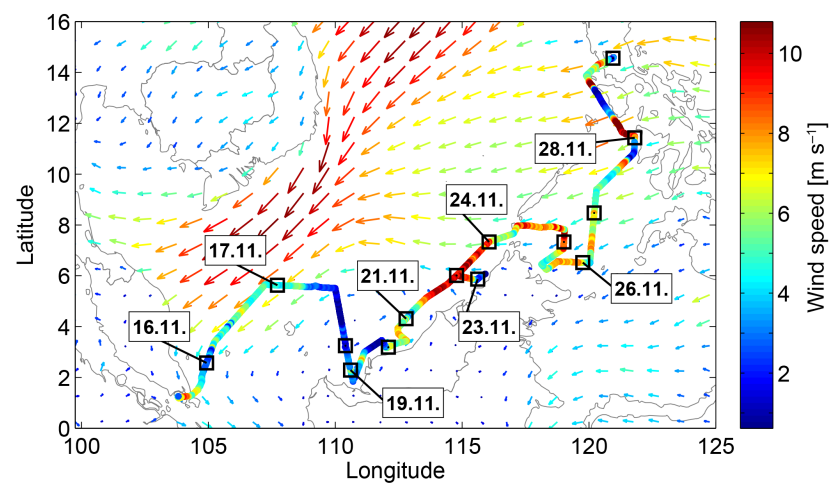

Figure 1. ERA-Interim mean wind field 15-30 November 2011 (arrows) and 10 min running mean of wind speed observed on $\mathrm{R} / \mathrm{V}$ Sonne as the cruise track. The black squares show the ships position at 00:00 UTC each day.

2013; Aschmann and Sinnhuber, 2013). An overview of the data and the methods used in this study is given in Sect. 2. Section 3 provides results from the meteorological observations along the cruise. Section 4 compares atmospheric VSLS measurements derived on R/V Sonne and R/A Falcon. The contribution of the oceanic emissions to the MABL and FT air is investigated and discussed in Sect. 5. Finally, a summary of the results is given in Sect. 6 .

\section{Data and methods}

\subsection{Ship and aircraft campaigns}

The R/V Sonne cruise started on 15 November 2011 in Singapore and ended on 29 November 2011 in Manila, Philippines (Fig. 1). The ship crossed the southwestern South China Sea towards the northwestern coast of Borneo from 16 to 19 November 2011. From 19 to 23 November 2011 the ship headed northeast along the northern coast of Borneo towards the Sulu Sea. Two diurnal stations took place on 18 November 2011 at $2.4^{\circ} \mathrm{N} / 110.6^{\circ} \mathrm{E}$ and on 22 November 2011 at $6.0^{\circ} \mathrm{N} / 114.8^{\circ} \mathrm{E}$. Two meetings between ship and aircraft were carried out on 19 and 21 November 2011, where R/A Falcon passed R/V Sonne within a distance of about $100 \mathrm{~m}$ several times to simultaneously measure the same air masses. On 24 November 2011 the ship entered the Sulu Sea and, after 4 days transect, R/V Sonne reached the Philippine coast.

Sixteen measurement flights were carried out with R/A Falcon between 16 November and 11 December 2011 as part of the SHIVA campaign to investigate halogenated VSLSs from the surface up to $13 \mathrm{~km}$ altitude over the South China and Sulu seas. Observations were performed between 1 and $8^{\circ} \mathrm{N}$, as well as 100 and $122^{\circ} \mathrm{E}$, from Miri, Borneo (Malaysia), as the aircraft base. A detailed description of the 
VSLS measurements and flight tracks can be found in Sala et al. (2014).

\subsection{Meteorological observations during SHIVA}

\subsubsection{Measurements on board R/V Sonne}

Meteorological parameters (temperature, air pressure, humidity and wind) were recorded at $20 \mathrm{~m}$ height every second. A 10 min running mean of these data is used for this study. An optical disdrometer ("ODM-470") measured the amount and intensity of precipitation during the cruise at $15 \mathrm{~m}$ height every minute (see Supplement for further details). To obtain atmospheric profiles of air temperature, relative humidity and wind from the surface to the stratosphere 67 GRAW DFM09 and 6 GRAW DFM-97 radiosondes were launched every $6 \mathrm{~h}$ at standard UTC times (00:00, 06:00, 12:00, 18:00) from the working deck of R/V Sonne at about $2 \mathrm{~m}$ a.s.l. At the $24 \mathrm{~h}$ stations, the launch frequency was increased to $2-$ $3 \mathrm{~h}$ to analyse short-term diel variations of the atmospheric boundary layer. The radiosonde data were integrated in near real time into the Global Telecommunication System (GTS) to improve meteorological reanalyses such as ERA-Interim (Dee et al., 2011), which is used as input data for the trajectory calculations (Sect. 5).

\subsubsection{Marine atmospheric boundary layer}

The MABL is the atmospheric surface layer above the ocean in which trace gas emissions are mixed vertically by convection and turbulence on a short timescale of about an hour (Stull, 1988; Seibert et al., 2000). The upper boundary of the MABL is either indicated by a stable layer, e.g. a temperature inversion, or by a significant reduction in air moisture. Determination of the MABL height can be achieved by theoretical approaches, e.g. using critical Bulk Richardson number (Troen and Mahrt, 1986; Vogelezang and Holtslag, 1996; Sorensen, 1998), or by practical approaches summarised in Seibert et al. (2000). An increase with height of the virtual potential temperature, the temperature an air parcel would acquire if adiabatically brought to standard surface pressure with regard to the humidity of the air parcel, identifies the base of the stable layer, which is typically found between $100 \mathrm{~m}$ and $3 \mathrm{~km}$ altitude (Stull, 1988). In this study, we use the height of the base of the stable layer increased by half of the stable layer depth as the definition for the MABL height. The height of the MABL is determined from the atmospheric profiles measured by radiosondes launched on board the ship, as described in detail by Fuhlbrügge et al. (2013).

\subsection{VSLS measurements and flux calculation}

VSLSs in marine surface air and seawater were sampled synchronously on R/V Sonne along the cruise track. From these data the oceanic emissions of the compounds during the SHIVA campaign were calculated (Sect. 2.3.3). Addition- ally, VSLSs were measured in the MABL and the FT by R/A Falcon (Sala et al., 2014; Tegtmeier et al., 2013).

\subsubsection{Atmospheric samples}

Air samples were taken 3 hourly along the cruise track and 1-2 hourly during the $24 \mathrm{~h}$ stations on R/V Sonne, resulting in a total of 195 samples during the cruise. The air was pressurised to $2 \mathrm{~atm}$ in pre-cleaned stainless steel canisters with a metal bellows pump. The samples were analysed within 6 months after the cruise at the Rosenstiel School for Marine and Atmospheric Sciences (RSMAS, Miami, Florida) according to Schauffler et al. (1999) with an instrumental precision of $\sim 5 \%$. Further details of the analysis are described in Montzka et al. (2003) and Fuhlbrügge et al. (2013). On R/A Falcon ambient air was analysed in situ by a GhOSTMS (gas chromatograph for the observation of stratospheric tracers coupled with a mass spectrometer) by the Goethe University of Frankfurt. Additionally, $700 \mathrm{~mL}$ glass flasks were filled with ambient air to a pressure of 2.5 bar with the R/A Falcon whole air sampler (WASP) and analysed within $48 \mathrm{~h}$ by a ground-based gas chromatography/mass spectrometry (GC/MS) instrument (Agilent 6973) of the University of East Anglia (Worton et al., 2008). During the flights GhOST measurements were conducted approximately every 5 min with a sampling time of $1 \mathrm{~min}$, while WASP samples were taken every 3-15 min with a sampling time of $2 \mathrm{~min}$. Further details on the instrumental precision and intercalibration on R/A Falcon are given in Sala et al. (2014). Given that the ground-based GC/MS investigated only brominated compounds, $\mathrm{CH}_{3} \mathrm{I}$ data are not available from WASP. Measurements from R/V Sonne and R/A Falcon were both calibrated with NOAA standards.

\subsubsection{Water samples}

VSLS seawater samples were taken 3 hourly from the moon pool of R/V Sonne at a depth of $5 \mathrm{~m}$ from a continuously working water pump. Measurements were interrupted between 16 November, 00:00 UTC, to 17 November 2011, 12:00 UTC, due to permission issues in the southwestern South China Sea. The water samples were analysed on board with a purge and trap system, attached to a gas chromatograph with mass spectrometric detection in single-ion mode and a precision of $10 \%$ determined from duplicates. The method is described in detail by Hepach et al. (2014).

\subsubsection{Sea-air flux}

The sea-air flux $(F)$ of $\mathrm{CHBr}_{3}, \mathrm{CH}_{2} \mathrm{Br}_{2}$ and $\mathrm{CH}_{3} \mathrm{I}$ is calculated with $k_{w}$ the concentration gradient and $\Delta c$ the concentration gradient between the water and atmospheric equilibrium concentrations (Eq. 1). For the determination of $k_{w}$, the wind speed-based parameterization of Nightingale et al. (2000) was used and a Schmidt number (Sc) correction to the carbon dioxide derived transfer coefficient $k_{\mathrm{CO}_{2}}$ after 
Quack and Wallace (2003) was applied for the three gases (Eq. 2).

$F=k_{w} \cdot \Delta c$

$k_{w}=k_{\mathrm{CO}_{2}} \cdot \frac{S c^{-\frac{1}{2}}}{600}$

Details on calculating the air-sea concentration gradient are further described in Hepach et al. (2014) and references therein.

\subsection{Oceanic VSLS contribution to the MABL and FT}

\subsubsection{Trajectory calculations}

The air mass transport from the surface to the FT was calculated with the Lagrangian particle dispersion model FLEXPART from the Department of Atmospheric and Climate Research of the Norwegian Institute for Air Research (Stohl et al., 2005). The model has been extensively evaluated in earlier studies (Stohl et al., 1998; Stohl and Trickl, 1999) and includes parameterisations for turbulence in the atmospheric boundary layer and the FT as well as moist convection (Stohl and Thomson, 1999; Forster et al., 2007). Meteorological input fields are retrieved from the ECMWF (European Centre for Medium-Range Weather Forecasts) assimilation reanalysis product ERA-Interim (Dee et al., 2011) with a horizontal resolution of $1^{\circ} \times 1^{\circ}$ and 60 vertical model levels. The shipbased 6-hourly radiosonde measurements were assimilated into the ERA-Interim data (Sect. 2.2.1) and provide air temperature, horizontal and vertical wind, boundary layer height, specific humidity, as well as convective and large-scale precipitation. For the trajectory analysis, 80 release points were defined along the cruise track. Time and position of these release events are synchronised with the water and air samples (Sect. 2.3). At each event, 10000 trajectories were launched from the ocean surface within a time frame of $\pm 30 \mathrm{~min}$ and an area of $\sim 400 \mathrm{~m}^{2}$ running for 16 days.

\subsubsection{VSLS source-loss estimate in the MABL}

The timescales of air mass transport derived from FLEXPART together with the oceanic emissions and chemical losses of the VSLSs are used for a mass balance source-loss estimate over the South China and Sulu seas. For each release event, a box given by the in situ height of the MABL and by the horizontal area of the trajectory releases $\left(\sim 400 \mathrm{~m}^{2}\right.$ centred on the measurement location) is defined. The MABL source-loss estimate is based on the assumption of a constant VSLS mixing ratio (given by the atmospheric measurements), a constant sea-air flux, the chemical loss (CL) rate and a VSLS homogeneous distribution with the box during each release.

The oceanic delivery (OD) is given as the contribution of VSLS sea-air flux (in mol per day) to the total number of
VSLSs in the box (in mol) in percentage per day. The loss of MABL air to the FT caused by vertical transport, denoted here as convective loss (COL), is calculated from the mean residence time of the FLEXPART trajectories in the observed MABL during each release and is given as a negative number in percentage per day. COL equals the loss of VSLSs from the MABL to the FT. The CL, in the form of reaction with $\mathrm{OH}$ and photolysis, is estimated in percentage per day (negative quantity) and is based on the tropical MABL lifetime estimates of 15 days for $\mathrm{CHBr}_{3}, 94$ days for $\mathrm{CH}_{2} \mathrm{Br}_{2}$ and 4 days for $\mathrm{CH}_{3} \mathrm{I}$ (Carpenter et al., 2014).

Relating the delivery of VSLSs from the ocean to the MABL (OD) and the loss of MABL air containing VSLSs to the FT (COL) results in an oceanic delivery ratio (ODR) (Eq. 3):

$$
\begin{aligned}
\mathrm{ODR} & =\frac{\mathrm{OD}\left[\% \mathrm{day}^{-1}\right]}{\operatorname{COL}\left[\% \mathrm{day}^{-1}\right]} \\
& =\frac{\text { sea-air flux contribution }\left[\% \mathrm{day}^{-1}\right]}{\operatorname{loss} \text { of MABL air to the FT }\left[\% \mathrm{day}^{-1}\right]} .
\end{aligned}
$$

Similarly, the CL in the MABL related to the MABL VSLS loss into the FT (COL) leads to a chemical loss ratio (CLR) (Eq. 4):

$$
\begin{aligned}
\mathrm{CLR} & =\frac{\mathrm{CL}\left[\% \mathrm{day}^{-1}\right]}{\operatorname{COL}\left[\% \mathrm{day}^{-1}\right]} \\
& =\frac{\text { loss through chemistry }\left[\% \mathrm{day}^{-1}\right]}{\text { loss of MABL air to the FT }\left[\% \text { day }^{-1}\right]} .
\end{aligned}
$$

The oceanic delivery, chemical loss and loss to the FT must be balanced by advective transport of air masses in and out of the box. We define the change of the VSLSs through advective transport as advective delivery (AD) in percentage per day (Eq. 5). Additionally, we define the ratio of change in VSLSs caused by AD to the loss of VSLSs out of the MABL to the FT as advective delivery ratio (ADR) in Eq. (6):

$$
\begin{aligned}
& \mathrm{AD}=\mathrm{COL}+\mathrm{CL}-\mathrm{OD} \\
& \mathrm{ADR}=\frac{\mathrm{AD}\left[\% \mathrm{day}^{-1}\right]}{\mathrm{COL}\left[\% \mathrm{day}^{-1}\right]}=1+\mathrm{CLR}-\mathrm{ODR} .
\end{aligned}
$$

Note that for the VSLSs within the MABL box, COL and $\mathrm{CL}$ are loss processes while OD and AD (besides very few exceptions for the latter) are source processes. In order to derive the ratios, we divided CL, OD and AD by COL.

In a final step, we relate the source-loss ratios (ODR, CLR and ADR) to the MABL VSLS volume mixing ratio VMR $_{\text {MABL }}$ in the box (Eqs. 7-9), in order to estimate VSLSs newly supplied from oceanic delivery (VMR $\mathrm{VDR}_{\mathrm{O} R}$ ), lost by chemical processes $\left(\mathrm{VMR}_{\mathrm{CLR}}\right)$ and supplied by advective transport $\left(\mathrm{VMR}_{\mathrm{ADR}}\right)$. 
$\mathrm{VMR}_{\mathrm{ODR}}=\mathrm{ODR} \cdot \mathrm{VMR}_{\mathrm{MABL}}$

$\mathrm{VMR}_{\mathrm{CLR}}=\mathrm{CLR} \cdot \mathrm{VMR}_{\mathrm{MABL}}$

$\mathrm{VMR}_{\mathrm{ADR}}=\mathrm{ADR} \cdot \mathrm{VMR}_{\mathrm{MABL}}$

\subsubsection{Oceanic and MABL VSLS contribution to the FT}

We use a simplified approach to calculate the mean contribution of boundary layer air masses observed from various oceanic regions in the South China and Sulu seas on the ship, and the oceanic compounds therein, to the FT. The contribution is determined as a function of time and altitude based on the distribution of the trajectories released at each measurement location along the ship track. According to R/A Falcon observations and our trajectory calculations we assume a well-mixed FT. Observations on R/V Sonne, however, are characterized by large variability and are considered to be representative for the area along the cruise track where the VSLSs were measured in the water and atmosphere. We constrain our calculations to this area and define 80 vertical columns along the cruise track. Each column extends horizontally over the area given by the starting points of the trajectories $(20 \mathrm{~m} \times 20 \mathrm{~m}$ centred on the measurement location) and vertically from the sea surface up to the highest point of R/A Falcon observations around $13 \mathrm{~km}$ altitude. For each of the 80 columns along the cruise track, 10000 trajectories were launched and assigned an identical MABL air parcel containing air with the VSLS mixing ratios observed on $\mathrm{R} / \mathrm{V}$ Sonne during the time of the trajectory release. The volume of the air parcel is given by the in situ height of the MABL and the horizontal extent of the release box $(20 \mathrm{~m} \times 20 \mathrm{~m}) \mathrm{di}-$ vided by 10000 trajectories. The transport of the MABL air parcels is specified by the trajectories, assuming that no mixing occurs between the parcels during the transport. Chemical loss of the VSLSs in each air parcel is taken into account through chemical degradation according to their specific tropospheric lifetimes. The VSLS mixing ratios in the FT from the aircraft measurements are considered representative for the entire South China and Sulu seas. Thus we average over the volume and mixing ratios of all trajectories, independent of their exact horizontal location. Due to the decreasing density of air in the atmosphere with height, the volume of the MABL air parcels expands along the trajectories with increasing altitude. The expanding MABL air parcels take up an increasing fraction of air within the FT column, which is taken into account in our calculations using density profiles from our radiosonde measurements.

We calculate the contribution of oceanic compounds to the FT up to $13 \mathrm{~km}$ altitude, the upper height of R/A Falcon observations, within the column above the measurement location. For each layer, the ratio $r_{\mathrm{MABL}}$ of the volume of the MABL air parcels with the VSLS mixing ratio $\mathrm{VMR}_{\mathrm{MABL}}$ to the whole air volume of the layer is calculated. The ratio of advected FT air with a mixing ratio $\mathrm{VMR}_{\mathrm{AFT}}$ to the whole air volume of the layer is $r_{\mathrm{AFT}}$ respectively, with $r_{\mathrm{MABL}}+r_{\mathrm{AFT}}=1$. In our simulation, the FT air with a mixing ratio $\mathrm{VMR}_{\mathrm{FT}}$ observed by $\mathrm{R} / \mathrm{A}$ Falcon at a specific height is composed of the MABL air parcels and of the advected FT air parcels (Eq. 10):

$$
\begin{aligned}
r_{\mathrm{MABL}} & \cdot \mathrm{VMR}_{\mathrm{MABL}}+r_{\mathrm{AFT}} \cdot \mathrm{VMR}_{\mathrm{AFT}} \\
& =\left(r_{\mathrm{MABL}}+r_{\mathrm{AFT}}\right) \cdot \mathrm{VMR}_{\mathrm{FT}} .
\end{aligned}
$$

The relative contribution $C_{\mathrm{MABL}}$ of VSLSs observed in the MABL to the VSLSs observed in the FT at height $z$ and time $t$ is computed in altitude steps of $500 \mathrm{~m}$ (Eq. 11):

$$
\begin{aligned}
& C_{\mathrm{MABL}}(z, t)[\%]= \\
& 100 \cdot\left(r_{\mathrm{MABL}}(z, t) \cdot \operatorname{VMR}_{\mathrm{MABL}}(\mathrm{CL}(t))\right) / \operatorname{VMR}_{\mathrm{FT}}(z) .
\end{aligned}
$$

The oceanic contribution $C_{\mathrm{ODR}}$ to the VSLSs in the FT is computed after Eq. (12):

$$
\begin{aligned}
& C_{\mathrm{ODR}}(z, t)[\%]= \\
& 100 \cdot\left(r_{\mathrm{MABL}}(z, t) \cdot \mathrm{VMR}_{\mathrm{ODR}}(\mathrm{CL}(t))\right) / \operatorname{VMR}_{\mathrm{FT}}(z) .
\end{aligned}
$$

The simplified approach also allows deriving mean VSLS mixing ratios accumulated in the FT from both MABL VSLS and oceanic emissions. The FT VSLS mixing ratios are simulated for each of the 80 columns by initiating a new trajectory release event using same meteorological conditions and VSLS MABL observations. The accumulated mean mixing ratio of a compound at a specific height $z$ is then iterated after Eq. (13):

$$
\begin{aligned}
\operatorname{VMR}_{\mathrm{FT}}(z) & =\sum_{i=1}^{n}\left(r_{\mathrm{MABL}}(z, t(i)) \cdot \operatorname{VMR}_{\mathrm{MABL}}(\mathrm{CL}(t(i)))\right. \\
& +\left(1-r_{\mathrm{MABL}}(z, t(i))\right) \cdot \operatorname{VMR}_{\mathrm{FT}}(z, t(i-1)) \\
& \cdot \mathrm{CL}(\mathrm{COL})) .
\end{aligned}
$$

Here, $n$ is the number of runs for each of the 80 profiles, according to the residence time of the trajectories in the MABL and the total runtime of the trajectories. For example a trajectory residence time of $7 \mathrm{~h}$ in the MABL in combination with a total trajectory runtime of 16 days leads to $n=(24 / 7) \cdot 16=$ 54. $r_{\text {MABL }}$ gives the volume ratio of MABL air parcels at height $z$ and time $t$ to the total volume of a specific height layer. $\mathrm{VMR}_{\mathrm{MABL}}$ gives the compounds mixing ratio in the air parcels including chemical degradation (CL) since the air was observed in the MABL. Since we use a mean tropospheric lifetime, CL and thus also $\mathrm{VMR}_{\mathrm{MABL}}(\mathrm{CL})$ are independent from the height $z$. The initial FT background mixing ratios $\left(\operatorname{VMR}_{\mathrm{FT}}(z, t(i=0))\right)$ are set to $0 \mathrm{ppt}$ for each VSLS, followed by $n$ times iteration of $\operatorname{VMR}_{\mathrm{FT}}(i-1)$. The difference between $\operatorname{VMR}_{\mathrm{FT}}(i=n-1)$ and $\operatorname{VMR}_{\mathrm{FT}}(i=n)$ during the 


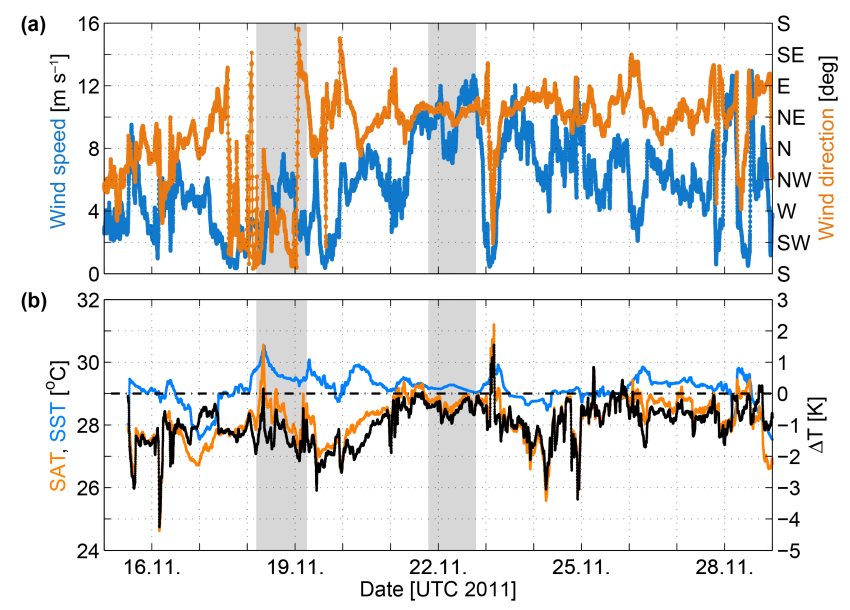

Figure 2. Time series of (a) wind speed (blue) and wind direction (orange) and (b) surface air temperature (SAT, orange) and sea surface temperature (SST, blue) on the left scale, as observed on R/V Sonne. The temperature difference of SAT and SST $(\Delta T)$ is given on the right scale in (b). The $\Delta T$ of $0 \mathrm{~K}$ is drawn by a dashed line. The shaded areas (grey) in the background show the $24 \mathrm{~h}$ stations. The data are averaged by a 10 min running mean.

last two steps of the iteration is less than $1 \%$ for each compound within the 16-day runtime.

The modelled overall mean FT mixing ratio is derived as the mean from the 80 individually calculated FT mixing ratios determined along the cruise. The oceanic contribution to

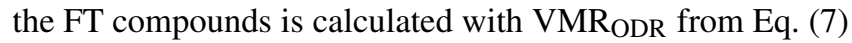
inserted as VMR $\mathrm{MABL}_{\mathrm{B}}$ in Eq. (13).

\section{Meteorological conditions in the MABL and the FT}

\subsection{Meteorology along the ship cruise}

Moderate to fresh trade winds dominated the South China and Sulu seas during the cruise (Fig. 1a-b), indicated by the overall mean wind direction of northeast $\left(50-60^{\circ}\right)$ and a mean wind speed of $5.5 \pm 2.9 \mathrm{~m} \mathrm{~s}^{-1}$. The wind observations reveal two different air mass origins. Between 15 and 19 November 2011 a gentle mean wind speed of $3.7 \pm 1.8 \mathrm{~m} \mathrm{~s}^{-1}$ with a northern wind direction was observed, influenced by a weak low-pressure system (not shown here) over the central South China Sea moving southwest and passing the ship position on 17 November 2011. During 20-29 November 2011 the wind direction changed to northeast and the mean wind speed increased to moderate $6.4 \pm 3.0 \mathrm{~m} \mathrm{~s}^{-1}$. A comparison between 6-hourly ERAInterim wind and a 6-hourly averaged mean of the observed wind on R/V Sonne reveals an underestimation of the wind speed by ERA-Interim along the cruise track by $1.6 \pm 1.4 \mathrm{~m} \mathrm{~s}^{-1}$ on average (not shown here). The mean deviation of the wind direction between reanalysis and observation is $2 \pm 37^{\circ}$. Reanalysis and observed wind speeds cor-

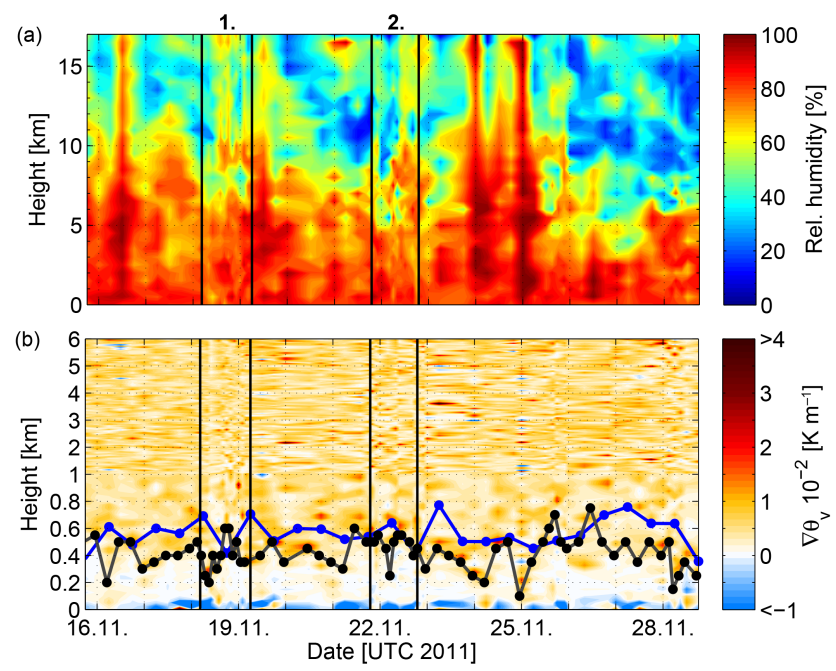

Figure 3. (a) Relative humidity from radiosondes up to $17 \mathrm{~km}$ height, the mean cold point tropopause level. The dashed lines and the two numbers above the figure indicate the two $24 \mathrm{~h}$ stations. (b) Virtual potential temperature gradient as indicator for atmospheric stability (red for stable, white for neutral and blue for unstable) with MABL height derived from radiosondes (black curve) and from ERA-Interim (blue curve). The $y$ axis is non-linear. The lower $1 \mathrm{~km}$ is enlarged to display the stability around the MABL height. The vertical lines and the two numbers above the figures indicate the two $24 \mathrm{~h}$ stations.

relate with $R=0.76$ and the wind directions with $R=0.86$, reflecting a good overall agreement between ship observation and ERA-Interim winds. With an observed mean surface air temperature (SAT) of $28.2 \pm 0.8^{\circ} \mathrm{C}$ and a mean SST of $29.1 \pm 0.5^{\circ} \mathrm{C}$ the SAT is on average $1.0 \pm 0.7^{\circ} \mathrm{C}$ below the SST, which benefits convection of surface air (Fig. 2). Indeed, enhanced convective activity and pronounced precipitation events have been observed during the cruise (Fig. S1 in the Supplement). Figure 3a shows the time series of the relative humidity measured by the radiosondes launched on $\mathrm{R} / \mathrm{V}$ Sonne from the surface up to the mean height of the cold point tropopause at $17 \mathrm{~km}$. Elevated humidity is found on average up to about $6 \mathrm{~km}$, which implies a distinct transport of water vapour to the mid-troposphere during the cruise by deep convection or advection of humid air from a nearby convective cell.

\subsection{Marine atmospheric boundary layer}

Higher SSTs than SATs (Fig. 2) cause unstable atmospheric conditions (negative values of the virtual potential temperature gradient) between the surface and about $50-100 \mathrm{~m}$ height (Fig. 3b). Surface air is heated by warmer surface waters and is enriched with humidity both benefiting moist convection. The stability of the atmosphere increases above $420 \pm 120 \mathrm{~m}$ and indicates the upper limit of the MABL at this altitude range derived from radiosonde data (Fig. 3b). 
Table 1. Mean \pm standard deviation and range of atmospheric mixing ratios observed on R/V Sonne (195 data points) and R/A Falcon (GhOST-MS with 513 and WASP GC/MS with 202 data points) in the MABL and the FT, water concentrations observed on R/V Sonne and the computed sea-air fluxes. MABL and FT mixing ratios on R/A Falcon are adopted from Sala et al. (2014) and Tegtmeier et al. (2013). The R/A Falcon MABL height was analysed to be $450 \mathrm{~m}$ (Sala et al., 2014).

\begin{tabular}{|c|c|c|c|c|c|c|}
\hline & & & & $\mathrm{CHBr}_{3}$ & $\mathrm{CH}_{2} \mathrm{Br}_{2}$ & $\mathrm{CH}_{3} \mathrm{I}$ \\
\hline \multirow{5}{*}{$\begin{array}{c}\text { Atmospheric mixing } \\
\text { ratios (ppt) }\end{array}$} & \multicolumn{3}{|c|}{ R/V Sonne } & $2.08 \pm 1.36$ & $1.17 \pm 0.19$ & $0.39 \pm 0.09$ \\
\hline & \multirow[t]{4}{*}{$\begin{array}{c}\text { R/A } \\
\text { Falcon }\end{array}$} & \multirow{2}{*}{$\begin{array}{l}\mathfrak{v} \\
\tilde{0} \\
\tilde{0}\end{array}$} & MABL & $\begin{array}{l}1.43 \pm 0.53 \\
{[0.42-3.42]}\end{array}$ & $\begin{array}{l}1.19 \pm 0.21 \\
{[0.58-1.89]}\end{array}$ & $\begin{array}{l}0.59 \pm 0.30 \\
{[0.29-3.23]}\end{array}$ \\
\hline & & & FT & $\begin{array}{l}0.56 \pm 0.17 \\
{[0.16-2.15]}\end{array}$ & $\begin{array}{l}0.87 \pm 0.12 \\
{[0.56-1.54]}\end{array}$ & $\begin{array}{l}0.26 \pm 0.11 \\
{[0.08-0.80]}\end{array}$ \\
\hline & & \multirow{2}{*}{$\frac{2}{3}$} & MABL & $\begin{array}{l}1.90 \pm 0.55 \\
{[0.99-3.78]}\end{array}$ & $\begin{array}{l}1.15 \pm 0.14 \\
{[0.85-1.59]}\end{array}$ & I \\
\hline & & & FT & $\begin{array}{l}1.17 \pm 0.50 \\
{[0.43-3.22]}\end{array}$ & $\begin{array}{l}0.88 \pm 0.14 \\
{[0.46-1.36]}\end{array}$ & I \\
\hline \multicolumn{4}{|c|}{ Water concentrations $\left(\mathrm{pmol} \mathrm{L}^{-1}\right)$} & $\begin{array}{l}19.94 \pm 17.90 \\
{[2.80-136.91]}\end{array}$ & $\begin{array}{l}4.99 \pm 2.59 \\
{[2.43-21.82]}\end{array}$ & $\begin{array}{l}3.82 \pm 2.43 \\
{[0.55-18.84]}\end{array}$ \\
\hline \multicolumn{4}{|c|}{ Sea-air flux $\left(\mathrm{pmol} \mathrm{m}^{-2} \mathrm{~h}^{-1}\right)$} & $\begin{array}{l}1486 \pm 1718 \\
{[-8-13149]}\end{array}$ & $\begin{array}{l}405 \pm 349 \\
{[16-2210]}\end{array}$ & $\begin{array}{l}433 \pm 482 \\
{[13-2980]}\end{array}$ \\
\hline
\end{tabular}

The MABL height given by ERA-Interim along the cruise track is, at $560 \pm 130 \mathrm{~m}$, systematically higher (not shown), but still within the upper range of the MABL height derived from the radiosonde measurements. The unstable conditions of the MABL and the increase of the atmospheric stability above the MABL reflect the characteristics of a convective, well-ventilated tropical boundary layer. In contrast to cold oceanic upwelling regions at the coasts with a stable and isolated MABL (Fuhlbrügge et al., 2013, 2015), the vertical gradient of the relative humidity measured by the radiosondes (Sect. 3.1) and the height of the MABL do not coincide. This is caused by increased mixing through and above the MABL by turbulence and convection, which leads to the convective, well-ventilated MABL.

\section{Atmospheric VSLSs over the South China and Sulu seas}

\subsection{Atmospheric surface observations on R/V Sonne}

Overall, the three VSLSs show a similar pattern of atmospheric mixing ratios along the cruise track with lower atmospheric surface abundances before 21 November 2011 and higher concentrations afterwards, which can be attributed to a change in air mass origin (Fig. 1). A decrease from 3.4 to $1.2 \mathrm{ppt}$ of $\mathrm{CHBr}_{3}$ occurs at the beginning of the cruise (Fig. 4a) when the ship left Singapore and the coast of the Malaysian Peninsula. On 16-19 November 2011, when the ship passed the southern South China Sea, lower mixing ratios $( \pm$ standard deviation $1 \sigma$ ) of $1.2 \pm 0.3 \mathrm{ppt}$ prevail and also the lowest mixing ratios for $\mathrm{CHBr}_{3}$ during the whole cruise of $0.8 \mathrm{ppt}$ are observed. At the coast of Borneo and the Philippines, the average mixing ratio of $\mathrm{CHBr}_{3}$ increases to $2.3 \pm 1.4$ ppt. The overall mean $\mathrm{CHBr}_{3}$ mixing ratio during the cruise is $2.1 \pm 1.4 \mathrm{ppt}$ (Table 1) and therefore higher than earlier reported $\mathrm{CHBr}_{3}$ observations of $1.2 \mathrm{ppt}$ in JanuaryMarch 1994 (Yokouchi et al., 1997), 1.1 ppt in September 1994 (Quack and Suess, 1999) and 1.5 ppt in June-July 2009 (Mohd Nadzir et al., 2014) further offshore in the South China Sea. The higher atmospheric mixing ratios during the $\mathrm{R} / \mathrm{V}$ Sonne cruise in November 2011 in contrast to the lower mixing ratios in these previous studies may point to stronger local sources, strong seasonal or interannual variations or even to long-term changes. $\mathrm{CH}_{2} \mathrm{Br}_{2}$ shows a mean mixing ratio of $1.2 \pm 0.2 \mathrm{ppt}$ (Table 1). Yokouchi et al. (1997) observed a lower mean atmospheric mixing ratio of $0.8 \mathrm{ppt}$ and Mohd Nadzir et al. (2014) of $1.0 \mathrm{ppt}$ in the South China Sea. An increase of the $\mathrm{CH}_{2} \mathrm{Br}_{2}$ mixing ratios from $1.0 \pm 0.1 \mathrm{ppt}$ to $1.3 \pm 0.2 \mathrm{ppt}$ is observed after 21 November 2011, coinciding with an increase of the $\mathrm{CH}_{3} \mathrm{I}$ concentrations from primarily $0.3 \pm 0.0 \mathrm{ppt}$ to $0.4 \pm 0.1 \mathrm{ppt}$ (Fig. $4 \mathrm{a}$ ). The highest mixing ratio of $\mathrm{CH}_{3} \mathrm{I}$ was detected in the southwestern Sulu Sea on 25 November 2011 with 0.8 ppt. The overall mean atmospheric mixing ratio for $\mathrm{CH}_{3} \mathrm{I}$, of $0.4 \pm 0.1 \mathrm{ppt}$ (Table 1) is lower than the mean of $0.6 \mathrm{ppt}$ observed by Yokouchi et al. (1997).

The concentration ratio of $\mathrm{CH}_{2} \mathrm{Br}_{2}$ and $\mathrm{CHBr}_{3}$ (Fig. 4b) has been used as an indicator of relative distance to the oceanic source, where a ratio of 0.1 was observed crossing strong coastal source regions (Yokouchi et al., 2005; Carpen- 
(a)

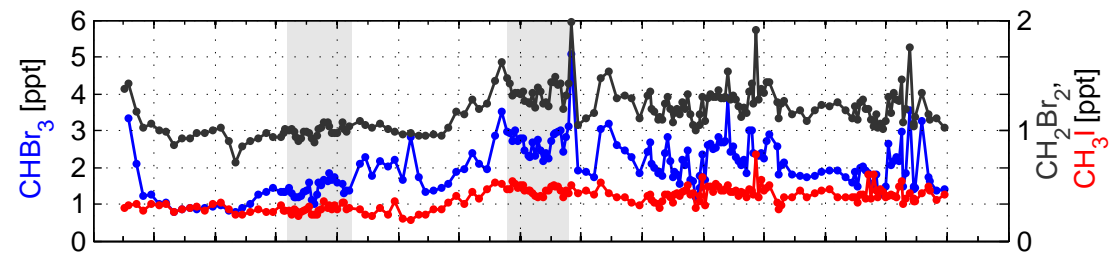

(b)

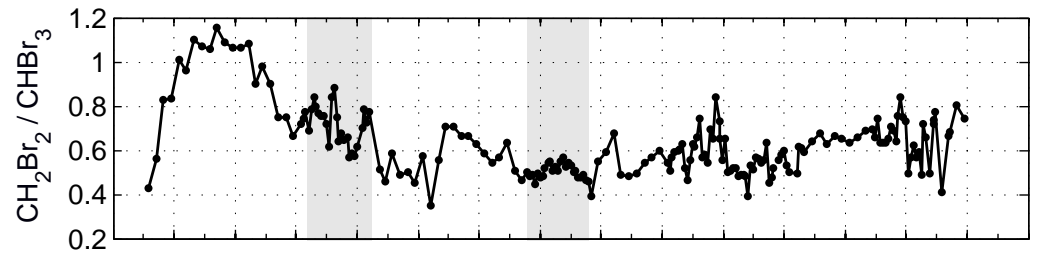

(c)

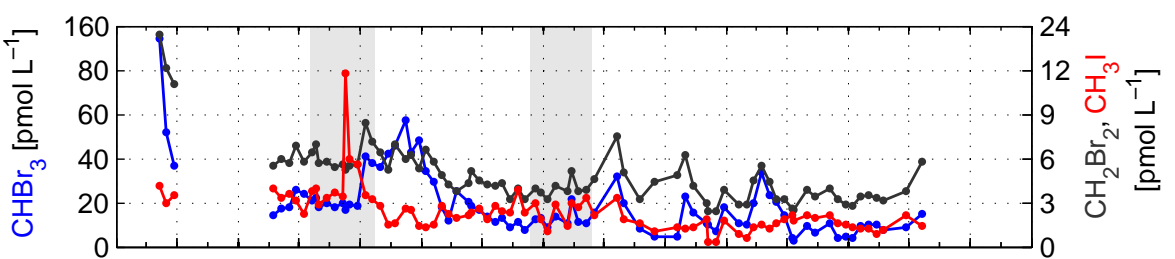

(d)

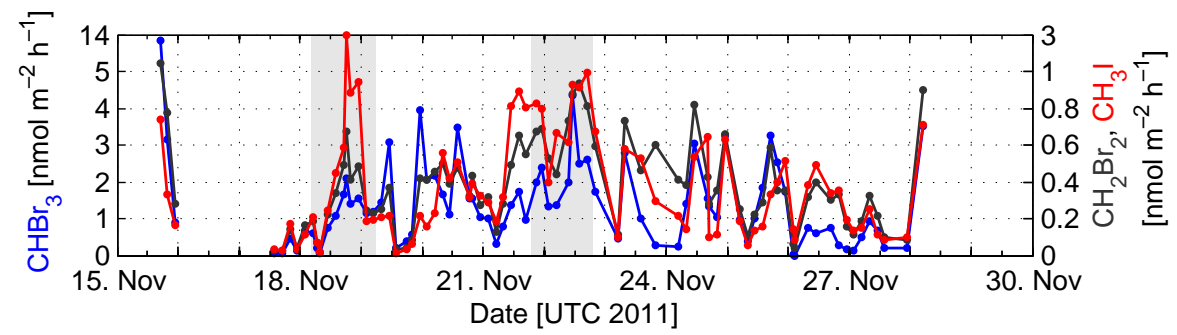

Figure 4. R/V Sonne measurements of (a) atmospheric mixing ratios of $\mathrm{CHBr}_{3}$ (blue), $\mathrm{CH}_{2} \mathrm{Br}_{2}$ (dark grey) and $\mathrm{CH}_{3} \mathrm{I}$ (red); (b) concentration ratio of atmospheric $\mathrm{CH}_{2} \mathrm{Br}_{2}$ and $\mathrm{CHBr}_{3}$; (c) water concentrations of $\mathrm{CH}_{3} \mathrm{I}, \mathrm{CHBr}_{3}$ and $\mathrm{CH}_{2} \mathrm{Br}_{2}$; and (d) calculated emissions of $\mathrm{CHBr} 3$, $\mathrm{CH}_{2} \mathrm{Br}_{2}$ and $\mathrm{CH}_{3} \mathrm{I}$ from atmospheric and water samples. The two shaded areas (light grey) in the background show the $24 \mathrm{~h}$ stations. $y$ axis for (c) and (d) are non-linear.

ter et al., 2003). The 10 times elevated $\mathrm{CHBr}_{3}$ has a much shorter lifetime, thus degrading more rapidly than $\mathrm{CH}_{2} \mathrm{Br}_{2}$, which increases the ratio during transport. Overall, the mean concentration ratio of $\mathrm{CH}_{2} \mathrm{Br}_{2}$ and $\mathrm{CHBr}_{3}$ is $0.6 \pm 0.2$, which suggests that predominantly older air masses are advected over the South China and Sulu seas.

\subsection{Oceanic surface concentrations and emissions from $\mathrm{R} / \mathrm{V}$ Sonne}

VSLSs in the surface seawater along the cruise track show highly variable distributions (Fig. $4 \mathrm{c}$ and Table 1). Oceanic $\mathrm{CHBr}_{3}$ surface concentrations range from 2.8 to $136.9 \mathrm{pmol} \mathrm{L}^{-1}$ with a mean of $19.9 \mathrm{pmol} \mathrm{L}^{-1}$ during the cruise, while $\mathrm{CH}_{2} \mathrm{Br}_{2}$ concentrations range from 2.4 to $21.8 \mathrm{pmol} \mathrm{L}^{-1}$ with a mean of $5.0 \mathrm{pmol} \mathrm{L}^{-1} . \mathrm{CHBr}_{3}$ and $\mathrm{CH}_{2} \mathrm{Br}_{2}$ have similar distribution patterns in the sampling region with near shore areas showing typically elevated concentrations. $\mathrm{CH}_{3} \mathrm{I}$ concentrations range from 0.6 to $18.8 \mathrm{pmol} \mathrm{L}^{-1}$ with a mean of $3.8 \mathrm{pmol} \mathrm{L}^{-1}$ and show a different distribution along the ship track which might be as- cribed to additional photochemical production of $\mathrm{CH}_{3} \mathrm{I}$ in the surface waters (e.g. Manley and Dastoor, 1988; Manley and de la Cuesta, 1997; Richter and Wallace, 2004).

High levels of all VSLSs are found in waters close to the Malaysian Peninsula, especially in the Singapore Strait on 16 November 2011, possibly showing an anthropogenic influence on the VSLS concentrations. VSLS concentrations decrease rapidly when the cruise track leads to open ocean waters. Along the west coast (19-23 November 2011) and northeast coast of Borneo (25 November 2011) bromocarbon concentrations are elevated, and especially $\mathrm{CHBr}_{3}$ concentrations increase in waters with lower salinities, indicating an influence by river run-off. Elevated $\mathrm{CHBr}_{3}$ concentrations are often found close to coasts with riverine inputs caused by natural sources and industrial and municipal effluents (see Quack and Wallace, 2003; Fuhlbrügge et al., 2013, and references therein).

Oceanic emissions were calculated from synchronised measurements of seawater concentrations and atmospheric mixing ratios, sea surface temperatures and wind speeds, measured on the ship (Sect. 2.3.3). The overall VSLS distri- 
bution along the ship track is opposite for the oceanic and atmospheric measurements (Fig. 4a-d). While the seawater concentrations of VSLSs generally decrease towards the Sulu Sea, the atmospheric mixing ratios increase, leading to a generally lower concentration gradient of the compounds between seawater and air in the Sulu Sea (not shown here).

Coinciding low VSLS atmospheric background concentrations, high SSTs, elevated oceanic VSLS concentrations and high wind speeds, lead to high emissions of VSLSs for the South China and Sulu seas (Fig. 4d) of $1486 \pm 1718 \mathrm{pmol} \mathrm{m}^{-2} \mathrm{~h}^{-1}$ for $\mathrm{CHBr}_{3}, \quad 405 \pm 349 \mathrm{pmol} \mathrm{m}^{-2} \mathrm{~h}^{-1}$ for $\mathrm{CH}_{2} \mathrm{Br}_{2}$ and $433 \pm 482 \mathrm{pmol} \mathrm{m}^{-2} \mathrm{~h}^{-1}$ for $\mathrm{CH}_{3} \mathrm{I}$. In particular, $\mathrm{CHBr}_{3}$ fluxes are very high and thus confirm elevated coastal fluxes from previous campaigns in tropical source regions (Quack et al., 2007). They often exceed $2000 \mathrm{pmol} \mathrm{m}^{-2} \mathrm{~h}^{-1}$ in the coastal areas and are sometimes higher than $6000 \mathrm{pmol} \mathrm{m}^{-2} \mathrm{~h}^{-1}$, as in the Singapore Strait on 15 and on 22 November 2011 at the northwestern coast of Borneo, which was also an area of strong convection (Figs. 1, 4b).

\subsection{VSLS intercomparison: R/A Falcon and R/V Sonne}

The two profiles of the bromocarbon mixing ratios (Sala et al., 2014) and the profile for $\mathrm{CH}_{3} \mathrm{I}$ (Tegtmeier et al., 2013) from the surface to $13 \mathrm{~km}$ altitude as observed on R/A Falcon with the GhOST and WASP instruments are shown in Fig. 5. Mean $\mathrm{CHBr}_{3}$ mixing ratios are $1.43 \mathrm{ppt}$ (GhOST) and $1.90 \mathrm{ppt}$ (WASP) in the MABL (0-450 m, determined from meteorological aircraft observations similarly as for the radiosondes; Sect. 2.2.2) and 0.56 ppt (GhOST) and $1.17 \mathrm{ppt}$ (WASP) in the FT $(0.45-13 \mathrm{~km}$; Table 1$)$. The GhOST mixing ratios in the MABL are lower than those observed on $\mathrm{R} / \mathrm{V}$ Sonne (2.08 ppt). A very good agreement of the measurements is given for the longer lived $\mathrm{CH}_{2} \mathrm{Br}_{2}$ with $1.17 \mathrm{ppt}$ (R/V Sonne), $1.19 \mathrm{ppt}$ (GhOST) and $1.15 \mathrm{ppt}$ (WASP). $\mathrm{CH}_{3} \mathrm{I}$ mixing ratios measured by GhOST are $0.59 \pm 0.30 \mathrm{ppt}$ within the MABL of $450 \mathrm{~m}$ height, which is about $0.2 \mathrm{ppt}$ higher than the values from R/V Sonne. Above the MABL, the average mixing ratio of $\mathrm{CH}_{3} \mathrm{I}$ decreases to $0.26 \pm 0.11 \mathrm{ppt}$ (Fig. 5).

$\mathrm{CHBr}_{3}$ and $\mathrm{CH}_{2} \mathrm{Br}_{2}$ concentrations in the MABL correlate with $R=0.83$ for all instruments (Fig. 6). $\mathrm{CHBr}_{3}$ and $\mathrm{CH}_{3} \mathrm{I}$ concentrations correlate with $R=0.55$ and $\mathrm{CH}_{2} \mathrm{Br}_{2}$ and $\mathrm{CH}_{3} \mathrm{I}$ with $R=0.66$; all correlations are significant at $99 \%$. Even higher correlations are found if only measurements on $\mathrm{R} / \mathrm{V}$ Sonne are taken into account with $R=0.92$ for $\mathrm{CHBr}_{3}$ and $\mathrm{CH}_{2} \mathrm{Br}_{2}, R=0.64$ for $\mathrm{CHBr}_{3}$ and $\mathrm{CH}_{3} \mathrm{I}$ and $R=0.77$ for $\mathrm{CH}_{2} \mathrm{Br}_{2}$ and $\mathrm{CH}_{3} \mathrm{I}$.

Comparisons of R/A Falcon and R/V Sonne data are obtained from their meetings on 19 and 21 November 2011 (Table 2), when aircraft and ship passed each other within $100 \mathrm{~m}$ distance several times, measuring the same air masses. During both meetings, deviations between the GhOST and WASP instruments on the aircraft are larger for the bromo-
Table 2. Mean atmospheric mixing ratios of $\mathrm{CHBr}_{3}, \mathrm{CH}_{2} \mathrm{Br}_{2}$ and $\mathrm{CH}_{3} \mathrm{I}$ observed on R/V Sonne and R/A Falcon during two case studies on 19 November 2011 at $3.2^{\circ} \mathrm{N}$ and $112.5^{\circ} \mathrm{E}$ and on 21 November 2011 at $4.6^{\circ} \mathrm{N}$ and $113.0^{\circ} \mathrm{E}$. During the two meetings two (one) measurements have been taken by R/V Sonne, 20 (5) measurements on R/A Falcon by GhOST and 17 (21) by WASP.

\begin{tabular}{lrrr}
\hline & $\mathrm{CHBr}_{3}(\mathrm{ppt})$ & $\mathrm{CH}_{2} \mathrm{Br}_{2}(\mathrm{ppt})$ & $\mathrm{CH}_{3} \mathrm{I}(\mathrm{ppt})$ \\
\hline 19 Nov 2011 & & & \\
R/V Sonne & 1.37 & 0.99 & 0.29 \\
R/A Falcon: & $1.02 / 1.37$ & $0.94 / 1.03$ & $0.45 /-$ \\
& GhOST/WASP & & \\
\hline 21 Nov 2011 & & & \\
R/V Sonne & 2.05 & 1.08 & 0.28 \\
R/A Falcon: & $1.63 / 2.00$ & $1.31 / 1.08$ & $0.82 /-$ \\
& GhOST/WASP & & \\
\hline
\end{tabular}
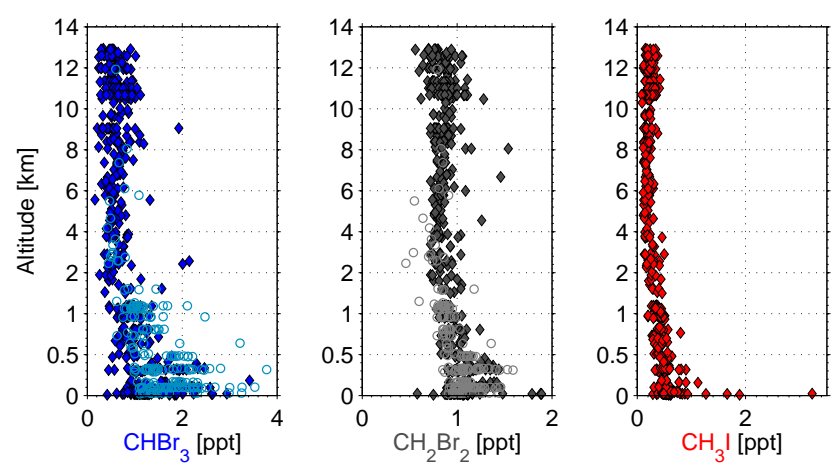

Figure 5. Vertical distribution $\mathrm{CHBr}_{3}$ (blue), $\mathrm{CH}_{2} \mathrm{Br}_{2}$ (grey) and $\mathrm{CH}_{3} \mathrm{I}$ (red) mixing ratios measured in situ by GhOST (diamonds) and with flasks by WASP (circles) on R/A Falcon. $\mathrm{CH}_{3} \mathrm{I}$ was only measured in situ by GhOST. The lower $2 \mathrm{~km}$ are non-linear displayed.

carbons than the deviation between the WASP and the ship measurements. According to Sala et al. (2014) the agreement between the GhOST and WASP instruments is within the expected uncertainty range of both instruments, which is then assumed to be also valid for the ship measurements (this study). The good agreement between WASP and ship data might be caused by the same sampling and analysis method, both using stainless steel canisters and subsequent analysis with GC/MS, while GhOST measures in situ with a different resolution. Since GhOST and WASP measurements together cover a larger spatial area and higher temporal resolution, a mean of both measurements is used in the following for computations in the free troposphere. For $\mathrm{CH}_{3} \mathrm{I}$ significantly higher mixing ratios were measured with GhOST during the meetings between ship and aircraft (Table 2). Whether this offset is systematic for the different methods needs further investigation. 

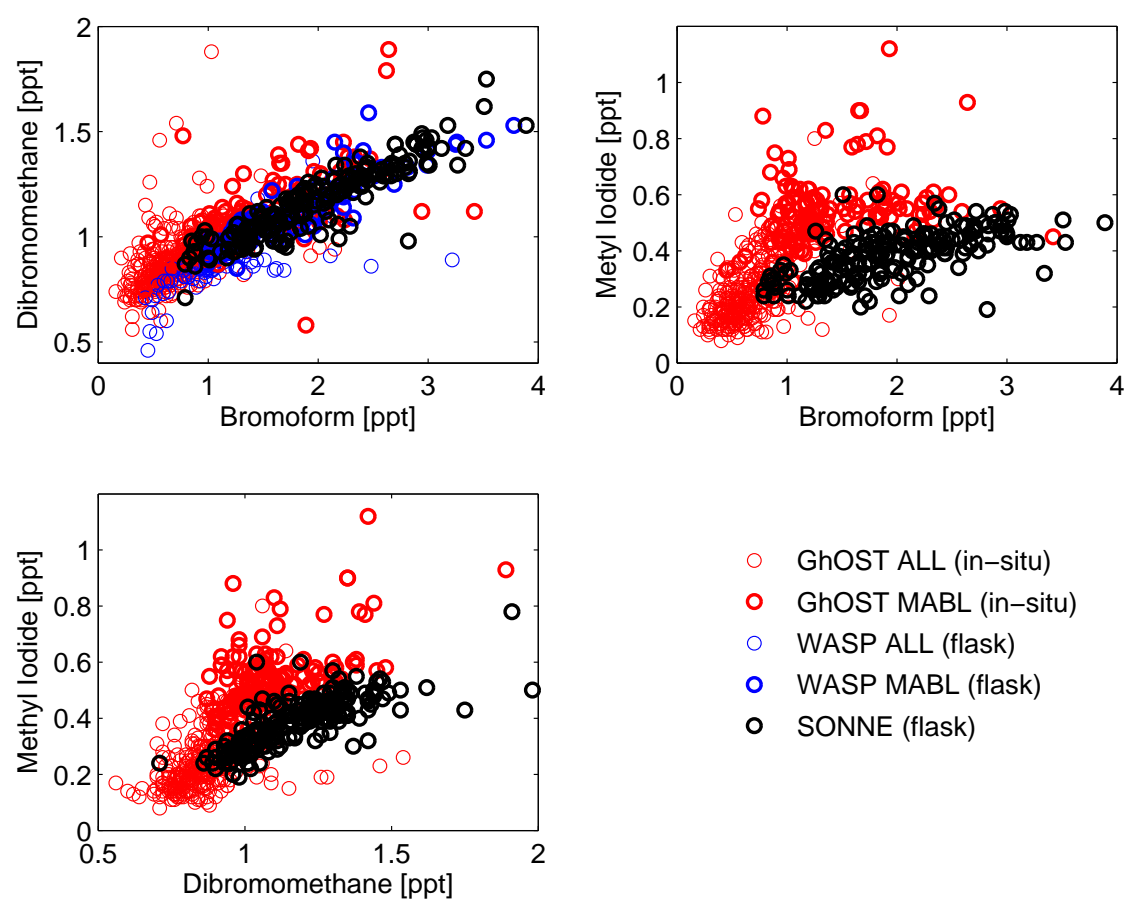

Figure 6. Correlation of bromoform and $\mathrm{CH}_{2} \mathrm{Br}_{2}$ (upper left), bromoform and $\mathrm{CH}_{3} \mathrm{I}$ (upper right), and $\mathrm{CH}_{2} \mathrm{Br}_{2}$ and $\mathrm{CH}_{3} \mathrm{I}$ (lower left) from GhOST and WASP for all heights (ALL) and only within the MABL (MABL) and from R/V Sonne.

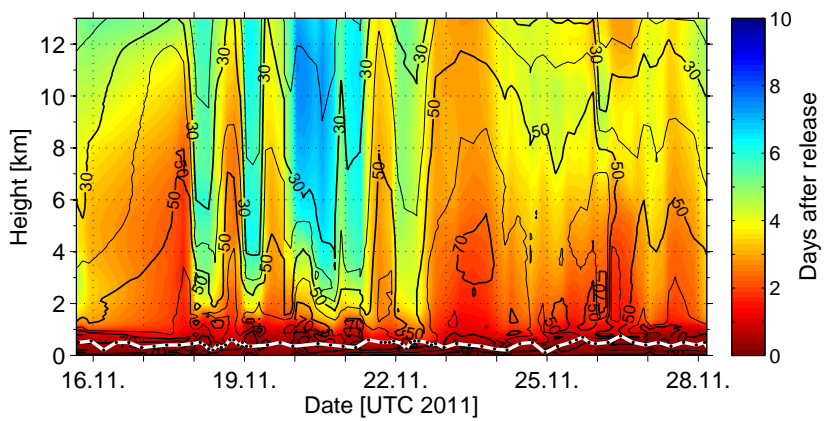

Figure 7. Forward trajectory runs along the cruise track with FLEXPART using ERA-Interim data. The black contour lines show the mean amount of trajectories (in \%) reaching a given height within the specific time (colour shading). The white line indicates the radiosonde MABL height.

\section{Air mass and VSLS transport from the surface to the free troposphere}

\subsection{Timescales and intensity of vertical transport}

Forward trajectories computed with FLEXPART starting at sea level along the cruise track yield an average MABL residence time of $7.8 \pm 3.5 \mathrm{~h}$ before the trajectories enter the FT (Fig. 7), reflecting a relatively fast exchange due to the convective well-ventilated MABL (Fig. 3). The trajectories generally show a strong contribution of surface air masses to the FT, despite some exceptions during 18-22 November 2011 (Fig. 7). Most intense and rapid transport of MABL air masses up to $13 \mathrm{~km}$ height occurs on 17 and 23 November 2011.

\subsection{Contribution of oceanic emissions to VSLSs in the MABL}

From the sea-air fluxes (Sect. 4.2) and the residence times of the surface trajectories in the MABL (Sect. 5.1), the OD and the COL were computed (Table 3 ) using the method described in Sect. 2.4.2.

Based on the OD and the COL, the ODR is calculated in order to characterise the relative contribution of the local oceanic emissions compared to the loss of MABL air into the FT (Table 3, Fig. 8). The average ODR during the cruise is $0.45 \pm 0.55$ for $\mathrm{CHBr}_{3}$, which means that the loss from the MABL to the FT is balanced to $45 \%$ by oceanic emissions along the cruise track. The ODR for $\mathrm{CH}_{2} \mathrm{Br}_{2}$ is $0.20 \pm 0.21$ and for $\mathrm{CH}_{3} \mathrm{I} 0.74 \pm 1.05$ respectively, suggesting that the major amount of $\mathrm{CH}_{3} \mathrm{I}$ originates from nearby sources. Similarly to the ODR the CL is related to the COL to derive the CLR for the VSLSs, which is $0.03 \pm 0.01$ for $\mathrm{CHBr}_{3}, 0.01 \pm 0.00$ for $\mathrm{CH}_{2} \mathrm{Br}_{2}$ and $0.09 \pm 0.04$ for $\mathrm{CH}_{3} \mathrm{I}$. When compared to the other source and loss processes, the chemical loss appears negligible for all three gases. The ratio of the ADR is $0.58 \pm 0.55$ for $\mathrm{CHBr}_{3}, 0.80 \pm 0.21$ for $\mathrm{CH}_{2} \mathrm{Br}_{2}$ and $0.35 \pm 1.02$, implying that most of the observed $\mathrm{CH}_{2} \mathrm{Br}_{2}(80 \%)$ in the MABL is 
Table 3. Mean \pm standard deviation of oceanic delivery (OD), convective loss (COL), chemical loss (CL), advective delivery (AD), oceanic delivery ratio (ODR), chemical loss ratio (CLR) and advective delivery ratio (ADR) for $\mathrm{CHBr}_{3}, \mathrm{CH}_{2} \mathrm{Br}_{2}$ and $\mathrm{CH}_{3} \mathrm{I}$.

\begin{tabular}{|c|c|c|c|c|c|c|c|}
\hline & OD $\left(\%\right.$ day $\left.^{-1}\right)$ & $\operatorname{COL}\left(\%\right.$ day $\left.^{-1}\right)$ & $\mathrm{CL}\left(\% \mathrm{day}^{-1}\right)$ & $\mathrm{AD}\left(\%\right.$ day $\left.^{-1}\right)$ & ODR & CLR & ADR \\
\hline $\mathrm{CHBr}_{3}$ & $116.4 \pm 163.6$ & $307.6 \pm 124.3$ & 7.1 & $198.2 \pm 199.7$ & $0.45 \pm 0.55$ & $0.03 \pm 0.01$ & $0.58 \pm 0.55$ \\
\hline $\mathrm{CH}_{2} \mathrm{Br}_{2}$ & $54.2 \pm 66.7$ & $307.6 \pm 124.3$ & 1.2 & $254.6 \pm 131.9$ & $0.20 \pm 0.21$ & $0.00 \pm 0.00$ & $0.80 \pm 0.21$ \\
\hline $\mathrm{CH}_{3} \mathrm{I}$ & $166.5 \pm 185.8$ & $307.6 \pm 124.3$ & 24.0 & $165.2 \pm 242.3$ & $0.74 \pm 1.05$ & $0.09 \pm 0.04$ & $0.35 \pm 1.02$ \\
\hline
\end{tabular}

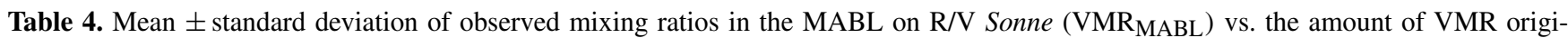
nating from oceanic emissions $\left(\mathrm{VMR}_{\mathrm{ODR}}\right)$, chemically degraded according to the specific lifetime (VMR $\mathrm{CLR}$ ), originating from advection $\left(\mathrm{VMR}_{\mathrm{ADR}}\right.$ ) and the flux from the MABL into the FT (flux $\mathrm{MABL}-\mathrm{FT}$ ) for $\mathrm{CHBr}_{3}, \mathrm{CH}_{2} \mathrm{Br}_{2}$ and $\mathrm{CH}_{3} \mathrm{I}$.

\begin{tabular}{lrrrrr}
\hline & $\mathrm{VMR}_{\mathrm{MABL}}(\mathrm{ppt})$ & $\mathrm{VMR}_{\mathrm{ODR}}(\mathrm{ppt})$ & $\mathrm{VMR}_{\mathrm{CLR}}(\mathrm{ppt})$ & $\mathrm{VMR}_{\mathrm{ADR}}(\mathrm{ppt})$ & Flux $_{\text {MABL-FT }}\left(\mathrm{pmol} \mathrm{m}^{-2} \mathrm{~h}^{1}\right)$ \\
\hline $\mathrm{CHBr}_{3}$ & $2.08 \pm 1.36$ & $0.89 \pm 1.12$ & $-0.06 \pm 0.04$ & $1.18 \pm 1.20$ & $4240 \pm 1889$ \\
$\mathrm{CH}_{2} \mathrm{Br}_{2}$ & $1.17 \pm 0.19$ & $0.25 \pm 0.26$ & $-0.01 \pm 0.00$ & $0.92 \pm 0.27$ & $2419 \pm 929$ \\
$\mathrm{CH}_{3} \mathrm{I}$ & $0.39 \pm 0.09$ & $0.28 \pm 0.40$ & $-0.04 \pm 0.02$ & $0.13 \pm 0.37$ & $865 \pm 373$ \\
\hline
\end{tabular}

Table 5. Correlation coefficients between wind speed and VSLS MABL mixing ratios (VMR $\mathrm{MABL}_{\mathrm{L}}$ ), the oceanic delivery (OD), the convective loss (COL) to the FT, the advective delivery (AD), computed as the residual of $\mathrm{OD}$, and the mixing ratios originating from the $\mathrm{OD}\left(\mathrm{VMR}_{\mathrm{ODR}}\right)$ and from the $\mathrm{AD}\left(\mathrm{VMR}_{\mathrm{ADR}}\right)$ of each compound. Bold numbers are significant at the $95 \%$ level ( $p$ value).

\begin{tabular}{lrrr}
\hline Wind speed & $\mathrm{CHBr}_{3}$ & $\mathrm{CH}_{2} \mathrm{Br}_{2}$ & $\mathrm{CH}_{3} \mathrm{I}$ \\
\hline VMR $_{\text {MABL }}$ & $\mathbf{0 . 5 5}$ & $\mathbf{0 . 5 7}$ & $\mathbf{0 . 5 6}$ \\
OD & $\mathbf{0 . 3 1}$ & $\mathbf{0 . 4 8}$ & $\mathbf{0 . 5 2}$ \\
COL & \multicolumn{3}{c}{$-\mathbf{0 . 3 3}$} \\
AD & -0.46 & 0.56 & $\mathbf{- 0 . 5 7}$ \\
VMR $_{\text {ODR }}$ & $\mathbf{0 . 5 2}$ & $\mathbf{0 . 7 2}$ & $\mathbf{0 . 6 2}$ \\
VMR $_{\text {ADR }}$ & -0.17 & $-\mathbf{0 . 3 1}$ & $\mathbf{- 0 . 4 9}$ \\
\hline
\end{tabular}

advected from other source regions. Applying the ODR to the observed mixing ratios in the MABL gives an estimate of the VSLSs originating from the local oceanic emissions (VMR ${ }_{\text {ODR }}$, Table 4). The local ocean emits a concentration that equates to $0.89 \pm 1.12 \mathrm{ppt} \mathrm{CHBr}_{3}, 0.25 \pm 0.26 \mathrm{ppt}$ $\mathrm{CH}_{2} \mathrm{Br}_{2}$ and $0.28 \pm 0.40 \mathrm{ppt} \mathrm{CH}_{3} \mathrm{I}$ in the MABL. The average transport from the MABL to the FT (flux MABL-FT), computed from the MABL concentrations and the trajectory residence time in the MABL, is $4240 \pm 1889 \mathrm{pmol} \mathrm{m}^{-2} \mathrm{~h}^{-1}$ for $\mathrm{CHBr}_{3}, \quad 2419 \pm 929 \mathrm{pmol} \mathrm{m}^{-2} \mathrm{~h}^{-1}$ for $\mathrm{CH}_{2} \mathrm{Br}_{2}$ and $865 \pm 373 \mathrm{pmol} \mathrm{m}^{-2} \mathrm{~h}^{-1}$ for $\mathrm{CH}_{3} \mathrm{I}$. Calculations with the ERA-Interim MABL height, which is on average $140 \mathrm{~m}$ higher than the one derived from the radiosondes, leads to similar estimates (Table S1).

Since the wind is a driving factor for oceanic emissions and advection of VSLSs, changes in wind speed are assumed to affect atmospheric VSLS mixing ratios in the MABL during this cruise. Significant correlations are found between wind speed and the observed mixing ratios of all three VSLSs in the MABL with correlation coefficients

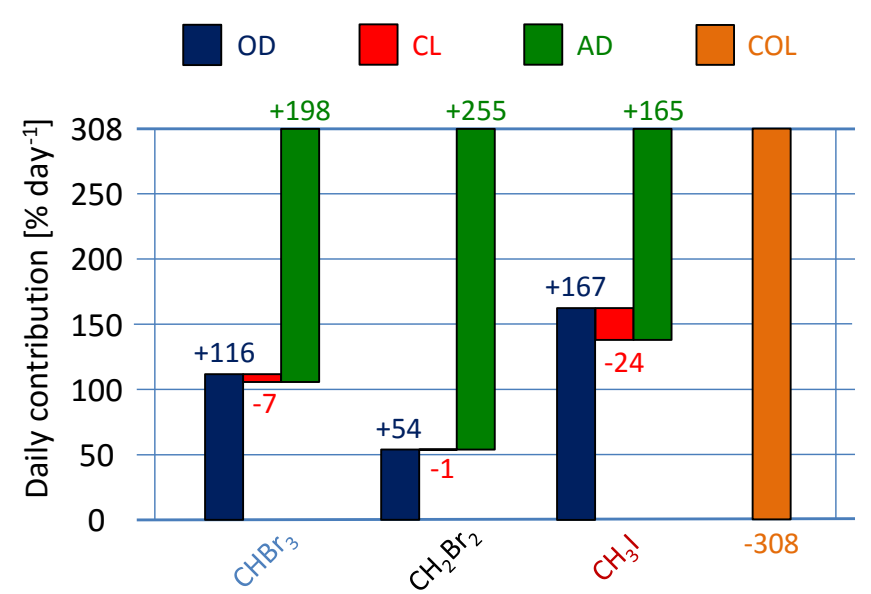

Figure 8. Average budgets of the oceanic delivery (OD, blue), chemical loss (CL, red), advective delivery ( $\mathrm{AD}$, green) and convective loss (COL, orange) of $\mathrm{CHBr}_{3}, \mathrm{CH}_{2} \mathrm{Br}_{2}$ and $\mathrm{CH}_{3} \mathrm{I}$ in the marine atmospheric boundary layer (MABL).

of $R=0.55\left(\mathrm{CHBr}_{3}\right), R=0.57\left(\mathrm{CH}_{2} \mathrm{Br}_{2}\right)$ and $R=0.56$ $\left(\mathrm{CH}_{3} \mathrm{I}\right)$ respectively (Table 5). Mixing ratios that originate from oceanic emissions (VMR $\mathrm{VDR}_{\mathrm{ODR}}$ ) correlate significantly to the wind speed with $R=0.52, R=0.72$ and $R=0.62$ respectively. In contrast, $\mathrm{VMR}_{\mathrm{ADR}}$, which is calculated as the residual from $\mathrm{VMR}_{\mathrm{ODR}}$, is negatively correlated to the wind speed with $R=-0.21, R=-0.32$ and $R=-0.53$. The correlations reveal that the contribution of oceanic emissions to MABL VSLSs increase for higher wind speeds, while the advective contribution decreases. 

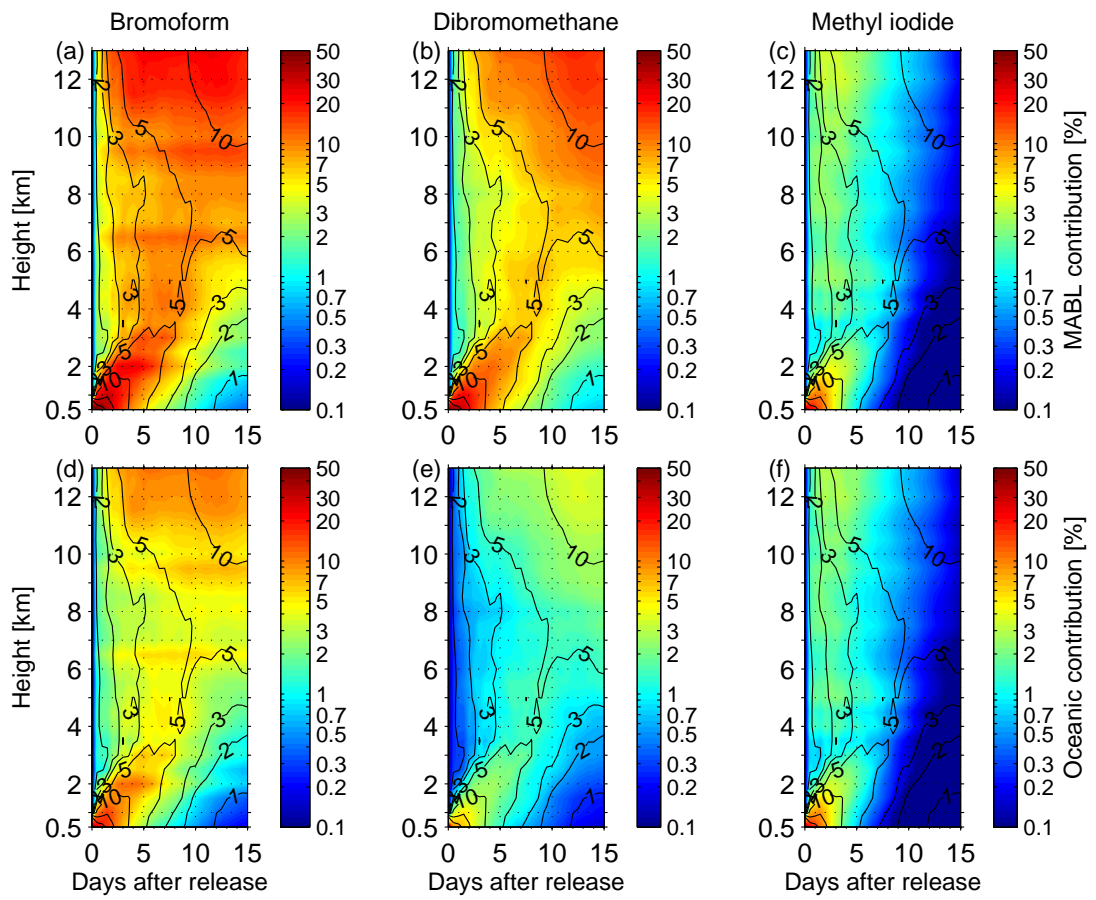

Figure 9. Mean MABL air contribution (a-c) and oceanic contribution (d-f) to observed FT mixing ratios observed by R/A Falcon for three VSLSs. The black contour lines show the mean portion of MABL air masses in the FT (\%), the colours show the oceanic contribution to the observed compounds in the FT at specific height and day after release (\%) including chemical degradation and the vertical density driven extension of MABL air masses. The scale of the coloured contour is logarithmic.

\subsection{Oceanic contribution to the FT}

\subsubsection{Identification of VSLS MABL air in the FT}

With a simplified approach (method description in Sect. 2.4.3) we are able to estimate the contribution of MABL air and regional marine sources observed on $\mathrm{R} / \mathrm{V}$ Sonne to the FT. Individual MABL air masses during the cruise show a strong contribution to the FT air up to $10 \%$ after 10 days (Fig. 9a-f). The MABL air is rapidly transported into high altitudes before it is dispersed in the FT column.

The average contribution of VSLS concentrations in the MABL air to the FT concentrations $\left(C_{\mathrm{MABL}}\right)$ is generally highest for $\mathrm{CHBr}_{3}$, with $10-15 \%$ between 4 and $10 \mathrm{~km}$ and up to $25 \%$ above $10 \mathrm{~km}$ height $3-10$ days after release in the MABL (coloured contours in Fig. 9a), followed by $\mathrm{CH}_{2} \mathrm{Br}_{2}$ (5-10\% below $10 \mathrm{~km}$ and up to $16 \%$ above $10 \mathrm{~km}$ height; Fig. 9b). The lowest contribution is found for the shortlived $\mathrm{CH}_{3} \mathrm{I}$ with up to $4 \%$ within 3 days (Fig. 9c). In general the contribution below $5 \mathrm{~km}$ height decreases after about 10 days, when most of the MABL air is transported into higher altitudes. For $\mathrm{CH}_{3} \mathrm{I}$, the chemical degradation, according to its short tropospheric lifetime of 3.5 days, leads to a rapid decrease of the contribution already 3 days after release.
To identify the contribution of the oceanic emissions to the FT VSLSs during the cruise, the VMR $\mathrm{ODR}_{\mathrm{O}}$ of each compound is used as the initial mixing ratio in the MABL air mass. For $\mathrm{CHBr}_{3}$ and $\mathrm{CH}_{2} \mathrm{Br}_{2}$ the local emissions contribute only up to 11 and $4 \%$ to the FT concentrations $\left(C_{\text {ODR }} ;\right.$ Fig. $\left.9 \mathrm{~d}-\mathrm{e}\right)$ compared to the $25 \%$, respectively $16 \%$, of $C_{\mathrm{MABL}}$. In contrast, the contribution of the local oceanic emissions of $\mathrm{CH}_{3} \mathrm{I}$ (Fig. 9f) is almost similar to the contribution of the observed MABL concentrations (Fig. 9c).

\subsubsection{Accumulated VSLSs in the free troposphere}

By simulating a steady transport of MABL air masses into the FT, mean accumulated VSLS mixing ratios in the FT along and during the cruise were computed (Fig. 10) as described in Sect. 2.4.3. The simulated FT mixing ratios of $\mathrm{CHBr}_{3}$ and $\mathrm{CH}_{2} \mathrm{Br}_{2}$ from the observed MABL (VMR $\mathrm{VABL}_{\text {) }}$ decrease on average from 2.1 and $1.2 \mathrm{ppt}$ at the surface to 0.6 and $0.8 \mathrm{ppt}$ at $3 \mathrm{~km}$ height. The simulated $\mathrm{CHBr}_{3}$ mixing ratios are constant up to $8 \mathrm{~km}$ height followed by an increase up to $0.9 \mathrm{ppt}$ at $13 \mathrm{~km}$ height. Simulated $\mathrm{CH}_{2} \mathrm{Br}_{2}$ mixing ratios increase between 3 and $11.5 \mathrm{~km}$ height up to $1.1 \mathrm{ppt}$ and remain constant above $11.5 \mathrm{~km}$ height. Simulated $\mathrm{CH}_{3} \mathrm{I}$ shows a decrease from $0.4 \mathrm{ppt}$ at the surface to $0.08 \mathrm{ppt}$ at $3 \mathrm{~km}$. Above this altitude, the simulated mixing ratios of $\mathrm{CH}_{3} \mathrm{I}$ are almost constant before they slowly increase above $9 \mathrm{~km}$ height to $0.10 \mathrm{ppt}$. 

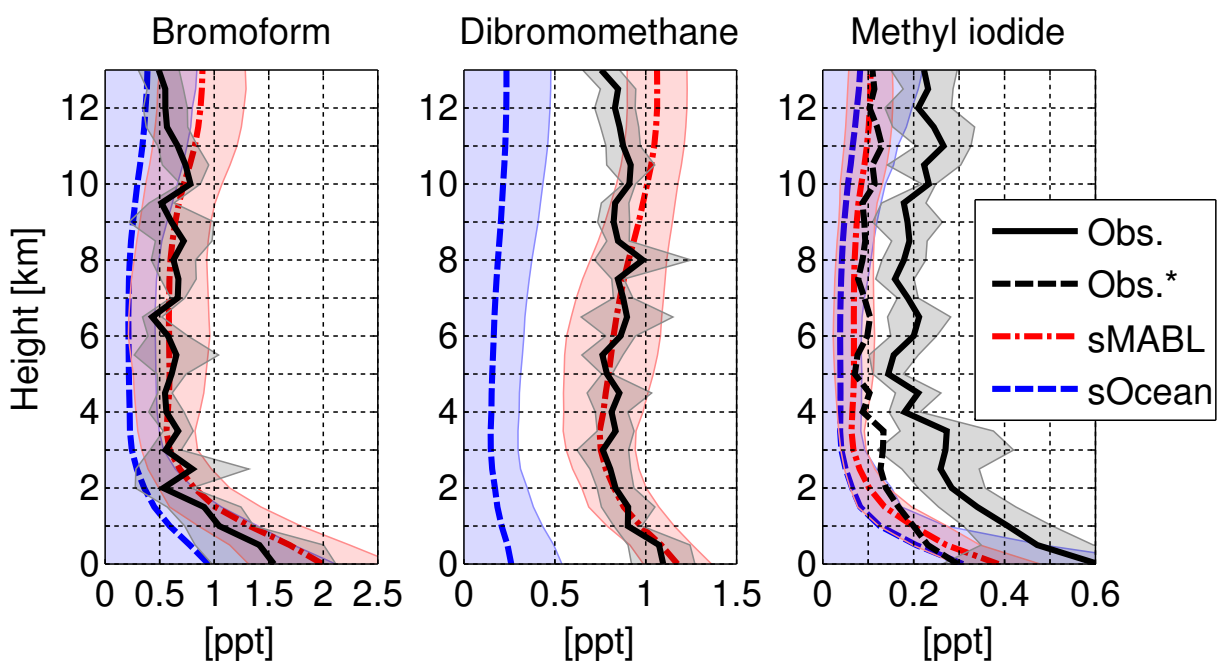

Figure 10. Mean FT mixing ratios (solid lines) and 1 standard deviation (shaded areas) from in situ and flask observations on R/A Falcon (Obs., black) vs. simulated mean FT mixing ratios from MABL air (sMABL, red) and oceanic emissions (sOcean, blue) observed by R/V Sonne. R/A Falcon in situ observations have been adjusted for $\mathrm{CH}_{3} \mathrm{I}$ (Obs.* , dashed black) according to measurement deviations during the meetings of R/V Sonne and R/A Falcon (Table 2; Sect. 4.3).

To estimate the accumulated FT mixing ratios solely from oceanic emissions, the $\mathrm{VMR}_{\mathrm{ODR}}$ is used as the initial MABL mixing ratio (Fig. 10). The simulated FT mixing ratios using either $\mathrm{VMR}_{\mathrm{MABL}}$ or $\mathrm{VMR}_{\mathrm{ODR}}$ as input reveal a similar vertical pattern, since both simulations are based on the same meteorology and trajectories. While FT mixing ratios based on $\mathrm{VMR}_{\mathrm{MABL}}$ and $\mathrm{VMR}$ ODR are similar for $\mathrm{CH}_{3} \mathrm{I}$ and differ by about $0.03 \mathrm{ppt}$ (due to the large oceanic contribution to the MABL mixing ratios), FT mixing ratios from $\mathrm{VMR}_{\mathrm{ODR}}$ are on average $\sim 0.4$ ppt lower for $\mathrm{CHBr}_{3}$ and $\sim 0.8$ ppt $\mathrm{CH}_{2} \mathrm{Br}_{2}$ than from $\mathrm{VMR}_{\mathrm{MABL}}$. Comparing the simulated $\mathrm{VMR}_{\mathrm{MABL}}$ FT mixing ratios with the observed FT mixing ratios from R/A Falcon reveals generally stronger vertical variations for the observations in contrast to the simulations. Still, $\mathrm{CHBr}_{3}$ observations are well reflected in the $\mathrm{VMR}_{\mathrm{MABL}}$ simulation between 2 and $11 \mathrm{~km}$ altitude. Also the simulated $\mathrm{CH}_{2} \mathrm{Br}_{2}$ in the FT based on VMR $\mathrm{VABL}_{\mathrm{A}}$ reflects the observations of R/A Falcon very well from the surface up to $9 \mathrm{~km}$ height. The $\mathrm{CH}_{3} \mathrm{I}$ simulations show a distinct underestimation of the observed FT mixing ratios. Adjusting the R/A Falcon values by the identified offset to R/V Sonne (Sect. 4.3 and Table 2) reveals a better agreement between observed and simulated FT mixing ratios (Fig. 10).

\subsubsection{Discussion}

Oceanic emissions of $\mathrm{CHBr}_{3}$ from the South China and Sulu seas contribute on average $45 \%$ to the simulated FT mixing ratios (Fig. 10). Simulated FT mixing ratios from MABL observations and observed FT mixing ratios agree quite well up to $11 \mathrm{~km}$ height. Above this altitude the simulated FT mixing ratios, in contrast to the observations increase, which is caused by an overestimation of the convective activity in our method. However, despite using this simple approach we are able to simulate mean FT mixing ratios up to $11 \mathrm{~km}$ height above the South China and Sulu seas in good agreement with observations. Thus, we assume that the observed MABL mixing ratios of $\mathrm{CHBr}_{3}$ and $\mathrm{CH}_{2} \mathrm{Br}_{2}$ are representative for the South China and Sulu seas.

On average, 45 and $20 \%$ of $\mathrm{CHBr}_{3}$ and $\mathrm{CH}_{2} \mathrm{Br}_{2}$ abundances in the MABL, observed on the ship, originate from local oceanic emissions along the ship track. Thus, advection from stronger source regions, possibly along the coast (for $\left.\mathrm{CHBr}_{3}\right)$ and from the West Pacific $\left(\mathrm{CH}_{2} \mathrm{Br}_{2}\right)$, are necessary to explain the observed MABL mixing ratios.

In contrast to $\mathrm{CHBr}_{3}$ and $\mathrm{CH}_{2} \mathrm{Br}_{2}$, the simulated mixing ratios of $\mathrm{CH}_{3} \mathrm{I}$ in the $\mathrm{FT}$ are strongly underestimated regardless of whether observed MABL mixing ratios or oceanic emissions are used. The offset between the simulated and observed $\mathrm{FT} \mathrm{CH}_{3} \mathrm{I}$ could be caused by additional strong sources of $\mathrm{CH}_{3} \mathrm{I}$ in the South China and Sulu seas. Furthermore, modelling or measurement uncertainties may add to this offset.

The simulations use constant atmospheric lifetimes for each compound and neglect lifetime variations with altitude which could impact the simulated abundances. However, the altitude variations of the $\mathrm{CH}_{3} \mathrm{I}$ lifetime in the MABL and FT are around 0.5 days (Carpenter et al., 2014) and thus impacts on the simulated abundances are quite small. Therefore, it seems unlikely that the lifetime estimate causes a large underestimation of the FT $\mathrm{CH}_{3} \mathrm{I}$. Additional uncertainties may arise from cloud-induced effects on photolysis rates (Tie et al., 2003) and $\mathrm{OH}$ levels (e.g. Tie et al., 2003; Rex et al., 2014) impacting the VSLS lifetimes. Deficiencies in the meteorological input fields and the FLEXPART model, in particular in the boundary layer and in the convection parame- 
terisations, would affect the transport of all compounds and their contribution to the FT concentrations in a similar way and thus seem to be unlikely as well. Ship and aircraft measurements revealed a possible instrumental offset for $\mathrm{CH}_{3} \mathrm{I}$ (Sect. 4.3). When we adjust the observations for the offset of $\mathrm{CH}_{3} \mathrm{I}$ between R/V Sonne and R/A Falcon the simulated and observed FT mixing ratios match better. Thus, an instrumental offset causing, at least partially, the calculated discrepancy for $\mathrm{CH}_{3} \mathrm{I}$ appears likely (Sect. 2.3.1).

Another explanation for the elevated $\mathrm{CH}_{3} \mathrm{I}$ in the FT is advection of fresh air with elevated $\mathrm{CH}_{3} \mathrm{I}$ mixing ratios in the FT from e.g. Southeast Asia or the Philippines. These areas are known to comprise strong sources for atmospheric $\mathrm{CH}_{3} \mathrm{I}$ from e.g. rice plantations (Redeker et al., 2003; Lee-Taylor and Redeker, 2005). In combination with convective activity over land, which is common in this area (Hendon and Woodberry, 1993), the high observed FT mixing ratios of $\mathrm{CH}_{3} \mathrm{I}$ could be explained, despite the low oceanic contribution during the cruise. The low observed MABL mixing ratios of $\mathrm{CH}_{3} \mathrm{I}$ on R/V Sonne may thus also not be representative for the area. Yokouchi et al. (1997) observed higher atmospheric $\mathrm{CH}_{3}$ I mixing ratios in the South China Sea.

Finally, the method of our simplified approach includes uncertainties as well. Different parameterisations for the transfer coefficient $k_{w}$ such as Liss and Merlivat (1986), which are at the lower end of reported parameterisations, and Wanninkhof and McGillis (1999), which are at the higher end, are discussed in Lennartz et al. (2015). Both lead to a reduction of the oceanic contribution to the atmospheric mixing ratios at the observed average moderate wind speeds $\left(\sim 6 \mathrm{~m} \mathrm{~s}^{-1}\right)$ when applied to our data. Nonetheless, the general conclusion that local oceanic sources of $\mathrm{CHBr}_{3}$ and $\mathrm{CH}_{3} \mathrm{I}$ significantly contribute to MABL mixing ratios remains for the cruise. In times of possible higher wind speeds $\left(>10 \mathrm{~m} \mathrm{~s}^{-1}\right)$, which are likely for this region, the flux variations between the different parameterisations as well as the oceanic contribution to atmospheric abundances, would increase. Further uncertainties may result from the approach to simulate FT mixing ratios from MABL observations, which does not include e.g. turbulent mixing or entrainment of different air masses containing different VSLS mixing ratios. Since observational studies quantifying the oceanic contribution to atmospheric abundances of VSLSs are quite rare, it is difficult to evaluate our findings at the moment and more studies for different oceanic regimes should be carried out to validate our results.

\section{Summary}

The contribution of oceanic VSLS emissions to MABL and FT air during the SHIVA campaign in November 2011 in the South China and Sulu seas was investigated in this study. Meteorological parameters were measured near the ocean surface and in the troposphere by regular radiosonde launches on R/V Sonne during the cruise. Oceanic VSLS emissions were determined from simultaneous atmospheric observations and sea surface water concentrations. The transport from the surface through the MABL into the FT was computed with the trajectory model FLEXPART.

The ship campaign was dominated by northeasterly winds with a characteristic moderate mean wind speed of $5.5 \mathrm{~m} \mathrm{~s}^{-1}$. The radiosonde launches revealed a convective, well-ventilated, weakly developed MABL with an average height of $420 \pm 120 \mathrm{~m}$ during the cruise. The 800000 forward trajectories, launched from the ocean surface along the cruise track, show a rapid exchange of MABL air with the FT within $7.8 \mathrm{~h}$. The observations on R/V Sonne reveal high mean ocean surface concentrations and emissions for $\mathrm{CHBr}_{3}\left(19.94 \mathrm{pmol} \mathrm{L}^{-1}\right.$ and $\left.1486 \mathrm{pmol} \mathrm{m}^{-2} \mathrm{~h}^{-1}\right)$, $\mathrm{CH}_{2} \mathrm{Br}_{2}\left(4.99 \mathrm{pmol} \mathrm{L}^{-1}\right.$ and $405 \mathrm{pmol} \mathrm{m}^{-2} \mathrm{~h}^{-1}$ ) and $\mathrm{CH}_{3} \mathrm{I}$ (3.82 $\mathrm{pmol} \mathrm{L}^{-1}$ and $433 \mathrm{pmol} \mathrm{m}^{-2} \mathrm{~h}^{-1}$ ) in comparison to other oceanic source regions. Atmospheric mixing ratios in the MABL, however, are relatively low with mean values of 2.08 ppt $\mathrm{CHBr}_{3}, 1.17$ ppt $\mathrm{CH}_{2} \mathrm{Br}_{2}$ and 0.39 ppt $\mathrm{CH}_{3} \mathrm{I}$. The contribution of the oceanic VSLS emissions to their MABL concentrations was evaluated by simple source-loss estimates, resulting in an ODR. The ODR for $\mathrm{CHBr}_{3}$ is 0.45 , revealing that up to $45 \%$ of $\mathrm{CHBr}_{3}$ mixing ratios in the MABL above the marginal seas originated, on average, from local oceanic sources, while $74 \%$ of $\mathrm{CH}_{3} \mathrm{I}$ and only $20 \%$ of $\mathrm{CH}_{2} \mathrm{Br}_{2}$ originates from the local ocean. This indicates that the long-lived $\mathrm{CH}_{2} \mathrm{Br}_{2}$ is largely advected in the MABL.

We extend our analysis to the FT using VSLS observations from R/A Falcon above the South China and Sulu seas. A single MABL air release contributes up to $25 \%$ $\left(\mathrm{CHBr}_{3}\right), 16 \%\left(\mathrm{CH}_{2} \mathrm{Br}_{2}\right)$ and $4 \%\left(\mathrm{CH}_{3} \mathrm{I}\right)$ to the FT mixing ratio (Sect. 5.3.1). The mean contributions of the local oceanic VSLSs to the FT within this MABL air release are up to $11 \%\left(\mathrm{CHBr}_{3}\right), 4 \%\left(\mathrm{CH}_{2} \mathrm{Br}_{2}\right)$ and $4 \%\left(\mathrm{CH}_{3} \mathrm{I}\right)$. In order to estimate whether the accumulated contributions from the single MABL air releases are sufficient to explain the accumulated VSLS mixing ratios observed in the FT, a steady transport of observed MABL air masses and oceanic emissions into the FT above the South China Sea was simulated. The simulations for $\mathrm{CHBr}_{3}$ based on the volume mixing ratios in the MABL (VMR $\mathrm{VABL}_{\mathrm{M}}$ ) reflect the observed mixing ratios in the FT up to $11 \mathrm{~km}$ height, while the simulations based on the local oceanic emissions $\left(\mathrm{VMR}_{\mathrm{ODR}}\right)$ explained about $45 \%$. In the MABL, the local oceanic emissions along the cruise track also explain half of the $\mathrm{CHBr}_{3}$. Thus, we conclude that the observed mixing ratios of $\mathrm{CHBr}_{3}$ in the MABL are influenced by stronger, possibly coastal sources, in the region.

$\mathrm{CH}_{2} \mathrm{Br}_{2}$ in the FT, simulated from observed MABL mixing ratios, shows a good agreement between observations and simulations up to $9 \mathrm{~km}$ height. $\mathrm{CH}_{3} \mathrm{I}$ in the FT is underestimated in the simulations, using both the observed MABL mixing ratios and the oceanic emissions. Even addressing an unresolved offset between the ship and aircraft data leads to 
an underestimation of $\mathrm{CH}_{3} \mathrm{I}$ in the FT, which points to additional $\mathrm{CH}_{3} \mathrm{I}$ sources, e.g. rice plantations in the region together with pronounced convection.

Our investigations show how oceanic emissions of VSLSs in a strong oceanic source region contribute to the observed atmospheric mixing ratios in the MABL. Furthermore, the contributions of these atmospheric mixing ratios, and the local oceanic VSLSs, to the observed VSLSs in the FT above this source region are derived. The results reveal strong links between oceanic emissions, atmospheric mixing ratios, MABL conditions and prevailing convective activity in the troposphere. The methods should be applied to other oceanic regions to derive a better process understanding of the contributions of air-sea gas exchange on atmospheric abundances. For the detection of future climate change effects on ocean surface trace gas emissions and their influence on atmospheric chemistry and composition it is important to study the complex interplay between oceanic sources and emissions, meteorology, atmospheric mixing ratios and transport to the upper atmosphere.

\section{The Supplement related to this article is available online at doi:10.5194/acp-16-7569-2016-supplement.}

Acknowledgements. This work was supported by the EU project SHIVA under grant agreement no. FP7-ENV-2007-1-226224 and by the BMBF grants SHIVA-Sonne (FKZ: 03G0218A), SOPRAN II (BMBF-FKZ: 03F0611A). SF was also partly funded by the grants ROMIC Threat (BMBF-FKZ: 01LG1217A) and OASIS-Sonne (BMBF-FKZ: 03G0235A). We thank the authorities of Malaysia and the Philippines for the permissions to work in their territorial waters, as well as the SHIVA coordinators Klaus Pfeilsticker and Marcel Dorf and all other SHIVA contributors. We acknowledge the ECMWF for the provision of ERA-Interim reanalysis data and the FLEXPART development team for the model used in this publication. We would also like to thank the captain and crew of R/V Sonne and the pilot in command and crew of R/A Falcon as well as the Projektträger Jülich (PTJ) and the Deutscher Wetterdienst (DWD) for the support. E. Atlas was supported by grant no. NNX12AH02G from the NASA Upper Atmosphere Research Program. We thank X. Zhu and L. Pope for technical support of canister analysis and C. Marandino for proof-reading the manuscript. Additional thanks goes to the Editor M. Schulz for leading the review process and his helpful comments to improve the manuscript, as well as to the two anonymous reviewers.

Edited by: M. Schulz

\section{References}

Aschmann, J. and Sinnhuber, B.-M.: Contribution of very shortlived substances to stratospheric bromine loading: uncertainties and constraints, Atmos. Chem. Phys., 13, 1203-1219, doi:10.5194/acp-13-1203-2013, 2013.
Aschmann, J., Sinnhuber, B.-M., Chipperfield, M. P., and Hossaini, R.: Impact of deep convection and dehydration on bromine loading in the upper troposphere and lower stratosphere, Atmos. Chem. Phys., 11, 2671-2687, doi:10.5194/acp-11-2671-2011, 2011.

Brinckmann, S., Engel, A., Bönisch, H., Quack, B., and Atlas, E.: Short-lived brominated hydrocarbons - observations in the source regions and the tropical tropopause layer, Atmos. Chem. Phys., 12, 1213-1228, doi:10.5194/acp-12-1213-2012, 2012.

Carpenter, L. and Liss, P.: On temperate sources of bromoform and other reactive organic bromine gases, J. Geophys. Res.-Atmos., 105, 20539-20547, doi:10.1029/2000JD900242, 2000.

Carpenter, L., Liss, P., and Penkett, S.: Marine organohalogens in the atmosphere over the Atlantic and Southern Oceans, J. Geophys. Res.-Atmos., 108, 4256, doi:10.1029/2002JD002769, 2003.

Carpenter, L. J., Reimann, S., Burkholder, J. B., Clerbaux, C., Hall, B. D., Hossaini, R., Laube, J. C., and Yvon-Lewis, S. A.: Update on Ozone-Depleting Substances (ODSs) and Other Gases of Interest to the Montreal Protocol, in: Scientific Assessment of Ozone Depletion: 2014, edited by: Engel, A. and Montzka, S. A., World Meteorological Organization, Geneva, 2014.

Dee, D., Uppala, S., Simmons, A., Berrisford, P., Poli, P., Kobayashi, S., Andrae, U., Balmaseda, M., Balsamo, G., Bauer, P., Bechtold, P., Beljaars, A., van de Berg, L., Bidlot, J., Bormann, N., Delsol, C., Dragani, R., Fuentes, M., Geer, A., Haimberger, L., Healy, S., Hersbach, H., Holm, E., Isaksen, L., Kallberg, P., Kohler, M., Matricardi, M., McNally, A., Monge-Sanz, B., Morcrette, J., Park, B., Peubey, C., de Rosnay, P., Tavolato, C., Thepaut, J., and Vitart, F.: The ERA-Interim reanalysis: configuration and performance of the data assimilation system, Q. J. Roy. Meteor. Soc., 137, 553-597, doi:10.1002/qj.828, 2011.

Dix, B., Baidara, S., Bresch, J., Hall, S., Schmidt, K., Wang, S., and Volkamer, R.: Detection of iodine monoxide in the tropical free troposphere, P. Natl. Acad. Sci. USA, 110, 2035-2040, doi:10.1073/pnas.1212386110, 2013.

Forster, C., Stohl, A., and Seibert, P.: Parameterization of convective transport in a Lagrangian particle dispersion model and its evaluation, J. Appl. Meteorol. Climatol., 46, 403-422, doi:10.1175/JAM2470.1, 2007.

Fuhlbrügge, S., Krüger, K., Quack, B., Atlas, E., Hepach, H., and Ziska, F.: Impact of the marine atmospheric boundary layer conditions on VSLS abundances in the eastern tropical and subtropical North Atlantic Ocean, Atmos. Chem. Phys., 13, 6345-6357, doi:10.5194/acp-13-6345-2013, 2013.

Fuhlbrügge, S., Quack, B., Atlas, E., Fiehn, A., Hepach, H., and Krüger, K.: Meteorological constraints on oceanic halocarbons above the Peruvian Upwelling, Atmos. Chem. Phys. Discuss., 15, 20597-20628, doi:10.5194/acpd-15-20597-2015, 2015.

Gschwend, P., Macfarlane, J., and Newman, K.: Volatile halogenated organic-compounds released to seawater from temperate marine macroalgae, Science, 227, 1033-1035, doi:10.1126/science.227.4690.1033, 1985.

Hendon, H. and Woodberry, K.: The diurnal cycle of tropical convection, J. Geophys. Res.-Atmos., 98, 16623-16637, doi:10.1029/93JD00525, 1993.

Hepach, H., Quack, B., Ziska, F., Fuhlbrügge, S., Atlas, E. L., Krüger, K., Peeken, I., and Wallace, D. W. R.: Drivers of diel and regional variations of halocarbon emissions from the trop- 
ical North East Atlantic, Atmos. Chem. Phys., 14, 1255-1275, doi:10.5194/acp-14-1255-2014, 2014.

Hossaini, R., Mantle, H., Chipperfield, M. P., Montzka, S. A., Hamer, P., Ziska, F., Quack, B., Krüger, K., Tegtmeier, S., Atlas, E., Sala, S., Engel, A., Bönisch, H., Keber, T., Oram, D., Mills, G., Ordóñez, C., Saiz-Lopez, A., Warwick, N., Liang, Q., Feng, W., Moore, F., Miller, B. R., Marécal, V., Richards, N. A. D., Dorf, M., and Pfeilsticker, K.: Evaluating global emission inventories of biogenic bromocarbons, Atmos. Chem. Phys., 13, 11819-11838, doi:10.5194/acp-13-11819-2013, 2013.

Hossaini, R., Chipperfield, M., Montzka, S., Rap, A., Dhomse, S., and Feng, W.: Efficiency of short-lived halogens at influencing climate through depletion of stratospheric ozone, Nat. Geosci., 8, 186-190, doi:10.1038/NGEO2363, 2015.

Hughes, C., Johnson, M., von Glasow, R., Chance, R., Atkinson, H., Souster, T., Lee, G., Clarke, A., Meredith, M., Venables, H., Turner, S., Malin, G., and Liss, P.: Climateinduced change in biogenic bromine emissions from the Antarctic marine biosphere, Global Biogeochem. Cy., 26, GB3019, doi:10.1029/2012GB004295, 2012.

Krüger, K. and Quack, B.: Introduction to special issue: the TransBrom Sonne expedition in the tropical West Pacific, Atmos. Chem. Phys., 13, 9439-9446, doi:10.5194/acp-13-9439-2013, 2013.

Leedham, E. C., Hughes, C., Keng, F. S. L., Phang, S.-M., Malin, G., and Sturges, W. T.: Emission of atmospherically significant halocarbons by naturally occurring and farmed tropical macroalgae, Biogeosciences, 10, 3615-3633, doi:10.5194/bg-10-36152013, 2013.

Lee-Taylor, J. and Redeker, K.: Reevaluation of global emissions from rice paddies of methyl iodide and other species, Geophys. Res. Lett., 32, L15801, doi:10.1029/2005GL022918, 2005.

Lennartz, S. T., Krysztofiak, G., Marandino, C. A., Sinnhuber, B.M., Tegtmeier, S., Ziska, F., Hossaini, R., Krüger, K., Montzka, S. A., Atlas, E., Oram, D. E., Keber, T., Bönisch, H., and Quack, B.: Modelling marine emissions and atmospheric distributions of halocarbons and dimethyl sulfide: the influence of prescribed water concentration vs. prescribed emissions, Atmos. Chem. Phys., 15, 11753-11772, doi:10.5194/acp-15-11753-2015, 2015.

Liss, P. S. and Merlivat, L.: Air-Sea Gas Exchange Rates: Introduction and Synthesis, in: The Role of Air-Sea Exchange in Geochemical Cycling, edited by: Buat-Menard, P., Reidel, D., and Norwell, M., Springer Netherlands, 113-127, 1986.

Liu, Y., Yvon-Lewis, S., Thornton, D., Butler, J., Bianchi, T., Campbell, L., Hu, L., and Smith, R.: Spatial and temporal distributions of bromoform and dibromomethane in the Atlantic Ocean and their relationship with photosynthetic biomass, J. Geophys. Res.Oceans, 118, 3950-3965, doi:10.1002/jgrc.20299, 2013.

Manley, S. and Dastoor, M.: Methyl-iodide (CH3I) production by kelp and assoviated microbes, Mar. Biol., 98, 477-482, doi:10.1007/BF00391538, 1988.

Manley, S. L. and de la Cuesta, J. L.: Methyl iodide production from marine phytoplankton cultures, Limnol. Oceanogr., 42, 142-147, 1997.

Montzka, S., Butler, J., Hall, B., Mondeel, D., and Elkins, J.: A decline in tropospheric organic bromine, Geophys. Res. Lett., 30, 1826, doi:10.1029/2003GL017745, 2003.

Montzka, S. A. and Reimann, S.: Ozone-depleting substances and related chemicals, Scientific Assessment of Ozone Depletion:
2010, Global Ozone Research and Monitoring Project - Report No. 52, Geneva, Switzerland, 2011.

Mohd Nadzir, M. S., Phang, S. M., Abas, M. R., Abdul Rahman, N., Abu Samah, A., Sturges, W. T., Oram, D. E., Mills, G. P., Leedham, E. C., Pyle, J. A., Harris, N. R. P., Robinson, A. D., Ashfold, M. J., Mead, M. I., Latif, M. T., Khan, M. F., Amiruddin, A. M., Banan, N., and Hanafiah, M. M.: Bromocarbons in the tropical coastal and open ocean atmosphere during the 2009 Prime Expedition Scientific Cruise (PESC-09), Atmos. Chem. Phys., 14, 8137-8148, doi:10.5194/acp-14-8137-2014, 2014.

Nightingale, P., Malin, G., Law, C., Watson, A., Liss, P., Liddicoat, M., Boutin, J., and Upstill-Goddard, R.: In situ evaluation of air-sea gas exchange parameterizations using novel conservative and volatile tracers, Global Biogeochem. Cy., 14, 373-387, doi:10.1029/1999GB900091, 2000.

Quack, B. and Suess, E.: Volatile halogenated hydrocarbons over the western Pacific between 43 degrees and 4 degrees N, J. Geophys. Res.-Atmos., 104, 1663-1678, doi:10.1029/98JD02730, 1999.

Quack, B. and Wallace, D.: Air-sea flux of bromoform: Controls, rates, and implications, Global Biogeochem. Cy., 17, 1023, doi:10.1029/2002GB001890, 2003.

Quack, B., Atlas, E., Petrick, G., and Wallace, D.: Bromoform and dibromomethane above the Mauritanian upwelling: Atmospheric distributions and oceanic emissions, J. Geophys. Res.-Atmos., 112, D09312, doi:10.1029/2006JD007614, 2007.

Quack, B., Krüger, K., Atlas, E., Tegtmeier, S., Großmann, K., Rex, M., von Glasow, R., Sommariva, R., and Wallace, D.: Halocarbon sources and emissions over the Western Pacific, Geophys. Res. Abstr., EGU2011-9732, EGU General Assembly 2011, Vienna, Austria, 2011.

Redeker, K., Meinardi, S., Blake, D., and Sass, R.: Gaseous emissions from flooded rice paddy agriculture, J. Geophys. Res.Atmos., 108, doi:10.1029/2002JD002814, 2003.

Rex, M., Wohltmann, I., Ridder, T., Lehmann, R., Rosenlof, K., Wennberg, P., Weisenstein, D., Notholt, J., Krüger, K., Mohr, V., and Tegtmeier, S.: A tropical West Pacific $\mathrm{OH}$ minimum and implications for stratospheric composition, Atmos. Chem. Phys., 14, 4827-4841, doi:10.5194/acp-14-4827-2014, 2014.

Richter, U. and Wallace, D.: Production of methyl iodide in the tropical Atlantic Ocean, Geophys. Res. Lett., 31, L23S03, doi:10.1029/2004GL020779, 2004.

Saiz-Lopez, A. and von Glasow, R.: Reactive halogen chemistry in the troposphere, Chem. Soc. Rev., 41, 6448-6472, doi:10.1039/c2cs35208g, 2012.

Saiz-Lopez, A., Fernandez, R. P., Ordóñez, C., Kinnison, D. E., Gómez Martín, J. C., Lamarque, J.-F., and Tilmes, S.: Iodine chemistry in the troposphere and its effect on ozone, Atmos. Chem. Phys., 14, 13119-13143, doi:10.5194/acp-1413119-2014, 2014.

Sala, S., Bönisch, H., Keber, T., Oram, D. E., Mills, G., and Engel, A.: Deriving an atmospheric budget of total organic bromine using airborne in situ measurements from the western Pacific area during SHIVA, Atmos. Chem. Phys., 14, 6903-6923, doi:10.5194/acp-14-6903-2014, 2014.

Schauffler, S., Atlas, E., Blake, D., Flocke, F., Lueb, R., LeeTaylor, J., Stroud, V., and Travnicek, W.: Distributions of brominated organic compounds in the troposphere and lower 
stratosphere, J. Geophys. Res.-Atmos., 104, 21513-21535, doi:10.1029/1999JD900197, 1999.

Seibert, P., Beyrich, F., Gryning, S., Joffre, S., Rasmussen, A., and Tercier, P.: Review and intercomparison of operational methods for the determination of the mixing height, Atmos. Environ., 34, 1001-1027, doi:10.1016/S1352-2310(99)00349-0, 2000.

Solomon, S.: Stratospheric ozone depletion: A review of concepts and history, Rev. Geophys., 37, 275-316, doi:10.1029/1999RG900008, 1999.

Sorensen, J.: Sensitivity of the DERMA long-range gaussian dispersion model to meteorological input and diffusion parameters, Atmos. Environ., 32, 4195-4206, doi:10.1016/S13522310(98)00178-2, 1998

Stohl, A. and Thomson, D.: A density correction for Lagrangian particle dispersion models, Bound.-Lay. Meteorol., 90, 155-167, doi:10.1023/A:1001741110696, 1999.

Stohl, A. and Trickl, T.: A textbook example of long-range transport: Simultaneous observation of ozone maxima of stratospheric and North American origin in the free troposphere over Europe, J. Geophys. Res.-Atmos., 104, 30445-30462, doi:10.1029/1999JD900803, 1999.

Stohl, A., Hittenberger, M., and Wotawa, G.: Validation of the Lagrangian particle dispersion model FLEXPART against largescale tracer experiment data, Atmos. Environ., 32, 4245-4264, doi:10.1016/S1352-2310(98)00184-8, 1998.

Stohl, A., Forster, C., Frank, A., Seibert, P., and Wotawa, G.: Technical note: The Lagrangian particle dispersion model FLEXPART version 6.2, Atmos. Chem. Phys., 5, 2461-2474, doi:10.5194/acp-5-2461-2005, 2005.

Stull, R.: An Introduction to Boundary Layer Meteorology, Kluwer Academic Publishers, Dordrecht, 1988.

Sturges, W. T., Williams, J., Roberts, G., Robinson, C., and Sander, R. (Eds.): The EU Project SHIVA (Stratospheric Ozone: Halogen Impacts in a Varying Atmosphere), Atmos. Chem. Phys., http: //www.atmos-chem-phys.net/special_issue306.html, 2012.

Tegtmeier, S., Krüger, K., Quack, B., Atlas, E. L., Pisso, I., Stohl, A., and Yang, X.: Emission and transport of bromocarbons: from the West Pacific ocean into the stratosphere, Atmos. Chem. Phys., 12, 10633-10648, doi:10.5194/acp-12-10633-2012, 2012.

Tegtmeier, S., Krüger, K., Quack, B., Atlas, E., Blake, D. R., Boenisch, H., Engel, A., Hepach, H., Hossaini, R., Navarro, M. A., Raimund, S., Sala, S., Shi, Q., and Ziska, F.: The contribution of oceanic methyl iodide to stratospheric iodine, Atmos. Chem. Phys., 13, 11869-11886, doi:10.5194/acp-13-11869-2013, 2013.

Tie, X., Madronich, S., Walters, S., Zhang, R., Rasch, P., and Collins, W.: Effect of clouds on photolysis and oxidants in the troposphere, J. Geophys. Res.-Atmos., 108, 4642, doi:10.1029/2003JD003659, 2003.

Troen, I. and Mahrt, L.: A simple-model of the atmospheric boundary-layer: Sensitivity to surface evaporation, Bound.-Lay. Meteorol., 37, 129-148, doi:10.1007/BF00122760, 1986.
Vogelezang, D. and Holtslag, A.: Evaluation and model impacts of alternative boundary-layer height formulations, Bound.-Lay. Meteorol., 81, 245-269, doi:10.1007/BF02430331, 1996.

von Glasow, R., von Kuhlmann, R., Lawrence, M. G., Platt, U., and Crutzen, P. J.: Impact of reactive bromine chemistry in the troposphere, Atmos. Chem. Phys., 4, 2481-2497, doi:10.5194/acp-42481-2004, 2004.

Wanninkhof, R. and McGillis, W.: A cubic relationship between air-sea $\mathrm{CO}_{2}$ exchange and wind speed, Geophys. Res. Lett., 26, 1889-1892, doi:10.1029/1999GL900363, 1999.

Worton, D., Mills, G., Oram, D., and Sturges, W.: Gas chromatography negative ion chemical ionization mass spectrometry: Application to the detection of alkyl nitrates and halocarbons in the atmosphere, J. Chromatogr. A, 1201, 112-119, doi:10.1016/j.chroma.2008.06.019, 2008.

Yang, X., Cox, R., Warwick, N., Pyle, J., Carver, G., O’Connor, F., and Savage, N.: Tropospheric bromine chemistry and its impacts on ozone: A model study, J. Geophys. Res.-Atmos., 110, D23311, doi:10.1029/2005JD006244, 2005.

Yang, X., Abraham, N. L., Archibald, A. T., Braesicke, P., Keeble, J., Telford, P. J., Warwick, N. J., and Pyle, J. A.: How sensitive is the recovery of stratospheric ozone to changes in concentrations of very short-lived bromocarbons?, Atmos. Chem. Phys., 14, 10431-10438, doi:10.5194/acp-14-10431-2014, 2014.

Yokouchi, Y., Mukai, H., Yamamoto, H., Otsuki, A., Saitoh, C., and Nojiri, Y.: Distribution of methyl iodide, ethyl iodide, bromoform, and dibromomethane over the ocean (east and southeast Asian seas and the western Pacific), J. Geophys. Res.-Atmos., 102, 8805-8809, doi:10.1029/96JD03384, 1997.

Yokouchi, Y., Hasebe, F., Fujiwara, M., Takashima, H., Shiotani, M., Nishi, N., Kanaya, Y., Hashimoto, S., Fraser, P., ToomSauntry, D., Mukai, H., and Nojiri, Y.: Correlations and emission ratios among bromoform, dibromochloromethane, and dibromomethane in the atmosphere, J. Geophys. Res.-Atmos., 110, D23309, doi:10.1029/2005JD006303, 2005.

Ziska, F., Quack, B., Abrahamsson, K., Archer, S. D., Atlas, E., Bell, T., Butler, J. H., Carpenter, L. J., Jones, C. E., Harris, N. R. P., Hepach, H., Heumann, K. G., Hughes, C., Kuss, J., Krüger, K., Liss, P., Moore, R. M., Orlikowska, A., Raimund, S., Reeves, C. E., Reifenhäuser, W., Robinson, A. D., Schall, C., Tanhua, T., Tegtmeier, S., Turner, S., Wang, L., Wallace, D., Williams, J., Yamamoto, H., Yvon-Lewis, S., and Yokouchi, Y.: Global sea-toair flux climatology for bromoform, dibromomethane and methyl iodide, Atmos. Chem. Phys., 13, 8915-8934, doi:10.5194/acp13-8915-2013, 2013. 